\title{
Glyphosate-based herbicide enhances the uterine sensitivity to estradiol in rats
}

\author{
Marlise Guerrero Schimpf1,2, María M Milesi1,2, Enrique H Luque1,2 and Jorgelina Varayoud1,2 \\ IInstituto de Salud y Ambiente del Litoral (ISAL, UNL-CONICET), Facultad de Bioquímica y Ciencias Biológicas, Universidad Nacional del Litoral, Santa \\ $\mathrm{Fe}$, Argentina \\ ²átedra de Fisiología Humana, Facultad de Bioquímica y Ciencias Biológicas, Universidad Nacional del Litoral, Santa Fe, Argentina \\ Correspondence should be addressed to J Varayoud: varayoud@fbcb.unl.edu.ar
}

\section{Abstract}

In a previous work, we detected that postnatal exposure to a glyphosate-based herbicide $(\mathrm{GBH})$ alters uterine development in prepubertal rats causing endometrial hyperplasia and increasing cell proliferation. Our goal was to determine whether exposure to low dose of a GBH during postnatal development might enhance the sensitivity of the uterus to an estrogenic treatment. Female Wistar pups were subcutaneously injected with saline solution (control) or $\mathrm{GBH}$ using the reference dose ( $2 \mathrm{mg} / \mathrm{kg} /$ day, EPA) on postnatal days (PND) 1, 3, 5 and 7. At weaning (PND21), female rats were bilaterally ovariectomized and treated with silastic capsules containing $17 \beta$-estradiol $(E 2,1 \mathrm{mg} / \mathrm{mL})$ until they were 2 months of age. On PND60, uterine samples were removed and processed for histology, immunohistochemistry and mRNA extraction to evaluate: (i) uterine morphology, (ii) uterine cell proliferation by the detection of Ki67, (iii) the expression of the estrogen receptors alpha (ESR1) and beta (ESR2) and (iv) the expression of WNT7A and CTNNB1. GBH-exposed animals showed increased luminal epithelial height and stromal nuclei density. The luminal and glandular epithelium were markedly hyperplastic in $43 \%$ of GBH-exposed animals. GBH exposure caused an increase in E2-induced cell proliferation in association with an induction of both ESR1 and ESR2. GBH treatment decreased membranous and cytoplasmic expression of CTNNB1 in luminal and glandular epithelial cells and increased WNT7A expression in the luminal epithelium. These results suggest that early postnatal exposure to a GBH enhances the sensitivity of the rat uterus to estradiol and induces histomorphological and molecular changes associated with uterine hyperplasia.

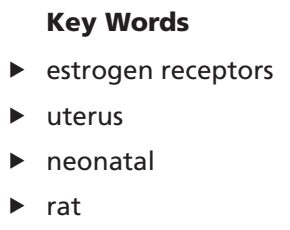

Journal of Endocrinology (2018) 239, 197-213

\section{Introduction}

Estrogens have been implicated as important etiologic agents in cancer of the female reproductive system (Chuffa et al. 2017). Likewise, several epidemiological studies have demonstrated a close correlation between environmental and/or occupational exposure to endocrine disrupting chemicals (EDCs) with estrogenic activity and cancer in women (Cohn et al. 2015, Lerro et al. 2015). Experimental studies performed in rodents have shown that environmental pollutants with estrogenic activity can induce pre-neoplastic uterine lesions as well as endometrial cancer. Yoshizawa et al. (2009) performed an in vivo study where female adult Harlan Sprague-Dawley rats orally exposed to chronic administration of dioxin and dioxin-like compounds (polychlorinated biphenyls and furans) showed increased incidence of cystic endometrial hyperplasia, luminal squamous metaplasia 
and carcinoma in the uterus. Other authors demonstrated that developmental exposure to diethylstilbestrol (DES) and bisphenol A (BPA) increases the incidence and severity of benign, premalignant and neoplastic uterine lesions in aged hamsters, rats and mice, including atypical hyperplasia and endometrial adenocarcinoma (Leavitt et al. 1981, Newbold et al. 1990, 2007, Vigezzi et al. 2015, 2016).

Among environmental pollutants, glyphosate-based herbicides (GBHs) have been one of the most intensively used pollutants over the last two decades worldwide (Benbrook 2016), resulting in increased environmental, plant and food contamination (Bai \& Ogbourne 2016, Primost et al. 2017, Rodrigues \& de Souza 2017, Zoller et al. 2017, Van Bruggen et al. 2018). Nonetheless, estimated human exposure from glyphosate maximum residue levels measured in food items and human urine samples has indicated that daily exposure to glyphosate is below the tolerable reference doses currently established by regulatory agencies (Niemann et al. 2015, Solomon 2016, Zoller et al. 2017). However, these tolerable doses of glyphosate are being questioned because they rely on outdated studies and may fail to protect human health or the environment (Vandenberg et al. 2017).

In the last years, there has been controversy and debate regarding the carcinogenic and the endocrine-disrupting potential of glyphosate and GBHs. Several bodies of experts have evaluated glyphosate carcinogenicity and have drawn different conclusions. The WHO's International Agency for Research on Cancer working group (IARC) concluded 'glyphosate is probably carcinogenic to humans (IARC Group 2A)' (IARC 2015), based on the evaluation of the publicly available evidence including data on the active ingredient glyphosate as well as on GBHs. In contrast, the European Food Safety Authority (EFSA) concluded 'glyphosate is unlikely to pose a carcinogenic hazard to humans' (EFSA 2015), based on all available data on the active ingredient glyphosate, including industry data (Portier et al. 2016, Tarazona et al. 2017). Similarly, different in vitro and in vivo studies have revealed possible endocrine-mediated effects of glyphosate and its commercial formulations on hormone-dependent tissues such as testis (Cassault-Meyer et al. 2014), ovary (Perego et al. 2017) and uterus (Guerrero Schimpf et al. 2017, Varayoud et al. 2017). Glyphosate was suggested to have endocrine-disrupting properties by inhibiting aromatase activity (Richard et al. 2005) and activating the estrogen receptor alpha (ESR1) and beta (ESR2) in breast cancer cells (Thongprakaisang et al. 2013, Mesnage et al. 2017). However, no evidence of potential interaction of glyphosate with endocrine pathways has been detected in the Endocrine Disruptor Screening Program (EDSP) conducted by the US
Environmental Protection Agency (EPA) (US EPA 2015). Thus, the carcinogenic and endocrine-disrupting potential of glyphosate and GBHs remains uncertain.

In a previous work, we demonstrated that the exposure to low dose $(2 \mathrm{mg} / \mathrm{kg}$ of body weight (bw)/day) of a $\mathrm{GBH}$ during the first postnatal days (PND) alters the development of the rat uterus by affecting uterine morphology and the expression of proteins that regulate uterine organogenetic differentiation during the neonatal (PND8) and prepubertal (PND21) periods (Guerrero Schimpf et al. 2017). In fact, GBH-induced endometrial hyperplasia in association with increased cell proliferation and deregulated different uterine morphoregulatory genes, such as ESR1, progesterone receptor (PR), homeobox A10 and wingless-type MMTV integration site family, member 7A (WNT7A) (Guerrero Schimpf et al. 2017). Alterations in uterine histoarchitecture and disruption of uterine morphoregulatory genes during critical periods of development might lead to reproductive anomalies during adulthood, such as infertility and early pregnancy loss and could promote the development of uterine neoplasias (Newbold et al. 1990, 1997, Varayoud et al. 2008, 2014). In this sense, we detected that early postnatal exposure to GBH causes post-implantation embryo loss in adult female rats associated with an altered decidualization response and defective uterine differentiation/proliferation (Ingaramo et al. 2016, 2017). However, less evidence are available about the capability of GBHs to promote uterine neoplasias.

Based on controversial and limited studies, we evaluated whether exposure to low-dose GBH during early stage of development might enhance the sensitivity of the uterus to an estrogenic prepubertal treatment. Female rats postnatally exposed to vehicle or GBH were bilaterally ovariectomized at weaning (PND21) and submitted to a chronic estrogen stimulation until PND60 to evaluate the following end points: (i) uterine morphology, (ii) uterine cell proliferation, (iii) the expression of the estrogen receptors (ERs) (ESR1 and ESR2) and (iv) the expression of WNT7A and $\beta$-catenin (CTNNB1), selected as E2-modulated targets that have been implicated in altered uterine E2 responsiveness and neoplasia.

\section{Materials and methods}

\section{Animals}

All procedures used in this study were performed in accordance with the principles and procedures outlined in the Guide for the Care and Use of Laboratory Animals 
issued by the US National Academy of Sciences and were approved by the Institutional Ethics Committee of the School of Biochemistry and Biological Sciences (Universidad Nacional del Litoral, Santa Fe, Argentina). Inbred Wistar strain rats were bred at the Department of Human Physiology (Santa Fe, Argentina) and housed in a controlled environment $\left(22^{\circ} \mathrm{C} \pm 2^{\circ} \mathrm{C}\right.$; lights on from 06:00 to 20:00 h) in stainless steel cages with sterile pine wood shavings as bedding. Rats had free access to pellet laboratory chow (16-014007 Rat-Mouse Diet, Nutrición Animal, Santa Fe, Argentina) and tap water. For more information regarding the food composition, see: Kass et al. (2012, Supplementary data Table 1); and, Vigezzi et al. (2016).

\section{Experimental design}

Pups were obtained from timed pregnant rats housed singly. After delivery (PND0), pups were sexed according to anogenital distance and cross-fostered by distributing the pups of each litter among the mothers. This procedure minimizes the use of siblings and thus avoids potential litter effects. Cross-fostered litters were adjusted to 8 pups, with 8 female pups per litter. When fewer than 8 females were available, an appropriate number of males were retained. Female pups from each foster mother were randomly assigned to one of the following postnatal treatment group: (1) control group receiving saline solution and (2) GBH group receiving a commercial formulation of glyphosate dissolved in saline solution ( $2 \mathrm{mg}$ of glyphosate/ $\mathrm{kg} \mathrm{bw}$ ). The glyphosate formulation used was Roundup FULL II, a liquid water-soluble formulation containing $66.2 \%$ of glyphosate potassium salt (equivalent to $54 \% \mathrm{w} / \mathrm{v}$ of glyphosate acid), as its active ingredient, coadjuvants and inert ingredients. Forty microliters were administered by subcutaneous (sc) injection in the nape of the neck every $48 \mathrm{~h}$ from PND1 to PND7. Each treatment day, the dose was calculated based on the concentration of glyphosate acid (54 $\mathrm{g}$ of glyphosate per $100 \mathrm{~mL}$ of $\mathrm{GBH}$ ) and the average body weight of the pups. The dose of GBH selected to perform this study is in the order of magnitude of the reference dose (RfD) of $1 \mathrm{mg} / \mathrm{kg}$ bw/day recently reassigned for glyphosate by the US EPA (2017). Moreover, this dose is representative of the glyphosate residues found in soybean grains (Arregui et al. 2004, Test Biotech 2013) and is in the order of magnitude of the environmental levels detected in our country (Peruzzo et al. 2008, Bonansea et al. 2017, Primost et al. 2017). Although the RfD for glyphosate is based on oral exposure, the subcutaneous administration enhances delivery of chemical compounds in an early postnatal exposure model (Milesi et al. 2012). The early postnatal model of exposure to endocrine disruptors has been extensively used in our laboratory in both rodents (Ramos et al. 2007, Varayoud et al. 2008, Monje et al. 2009, Milesi et al. 2015, Ingaramo et al. 2016, 2017, Guerrero Schimpf et al. 2017) and lambs (Rivera et al. 2011) and has been demonstrated as a persuasive paradigm to study short- and long-term consequences of neonatal exposure to hormonally active substances (Rivera et al. 2015). As previously reported (Guerrero Schimpf et al. 2017), GBH postnatal treatment (with $2 \mathrm{mg} / \mathrm{kg}$ bw/day in pups every $48 \mathrm{~h}$ from PND1 to PND7) produced no alterations in maternal care and nursing between the experimental groups. No signs of acute or chronic toxicity were observed in the litters, and no differences in weight gain between GBH and control pups were recorded during the experiment. A schematic representation of the experimental design is shown in Fig. 1.

\section{Ovariectomy, estrogen treatment and sample collection}

To study the long-term effects of postnatal GBH exposure on uterine sensitivity to E2, we used a model of prepubertal ovariectomized (OVX) rats submitted to chronic estrogen

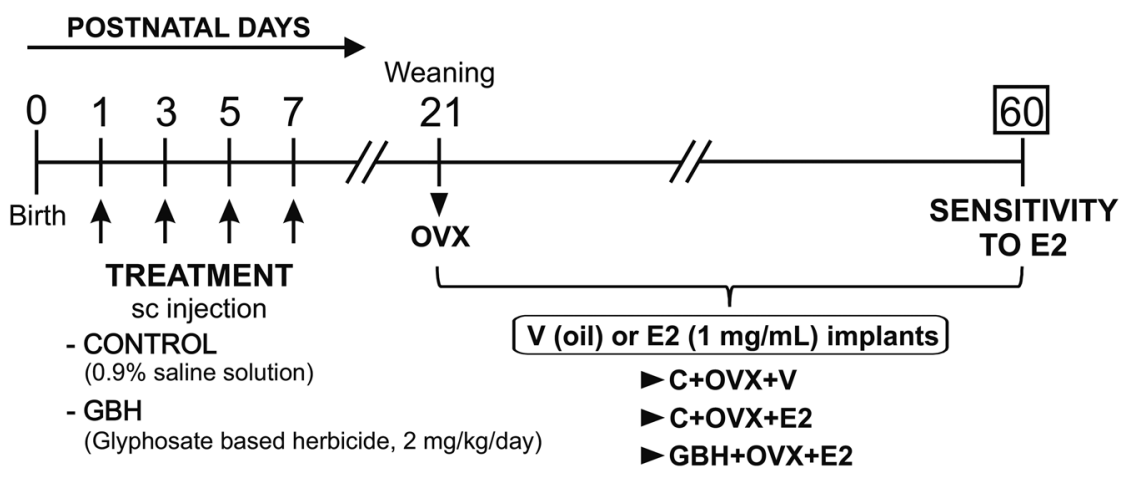

\section{Figure 1}

Schematic representation of the experimental protocol used to investigate the effects of postnatal exposure to a glyphosate-based herbicide (GBH) on uterine sensitivity to 17ק-estradiol (E2). C, control; OVX, ovariectomy; sc, subcutaneous; $V$, vehicle (corn oil). https://joe.bioscientifica.com https://doi.org/10.1530/JOE-18-0207 (c) 2018 Society for Endocrinology Published by Bioscientifica Ltd.
Printed in Great Britain 
treatment (Fig. 1). At weaning (PND21), control (C) and postnatally GBH-exposed female rats were anesthetized with a solution of ketamine:xylazine:acepromazine, $50: 5: 1 \mathrm{mg} / \mathrm{mL}$. The solution was prepared by mixing $1.0 \mathrm{~mL}$ of ketamine hydrochloride $(50 \mathrm{mg} / \mathrm{mL}$, Ketamina 50, Holliday-Scott, Buenos Aires, Argentina), $0.25 \mathrm{~mL}$ of xylazine hydrochloride $(20 \mathrm{mg} / \mathrm{mL}$, Kensol König, Buenos Aires, Argentina) and $0.1 \mathrm{~mL}$ of acepromazine maleate $(10 \mathrm{mg} / \mathrm{mL}$, Acedan, Holliday-Scott, Buenos Aires, Argentina). The anesthetic solution was administered intraperitoneally at a dose of $135 \mu \mathrm{L} / 100 \mathrm{gbw}$. Animals were bilaterally OVX to avoid endogenous estradiol (E2) variability. A group of control $(\mathrm{C}+\mathrm{OVX}+\mathrm{E} 2, n=8)$ and $\mathrm{GBH}-$ exposed $(\mathrm{GBH}+\mathrm{OVX}+\mathrm{E} 2, n=7)$ females were submitted to a chronic estrogen treatment, using silastic capsules (inner/outer diameter: 1.98/3.18mm, $19 \mathrm{~mm}$ in length, Dow Corning Corp., Midland, MI, USA) containing $1 \mathrm{mg}$ of $17 \beta$-estradiol/ml (Sigma-Aldrich) dissolved in corn oil. The capsules were preincubated at $37^{\circ} \mathrm{C}$ in phosphate buffer for $24 \mathrm{~h}$ to stabilize the release of E2, and then were implanted (one per animal) subcutaneously between the shoulder blades during the anesthesia used at ovariectomy. In order to characterize the uterine response to exogenous E2 treatment, we performed a pilot experiment using OVX prepubertal rats that were not exposed to GBH. For that purpose, another set of control females was implanted with capsules filled with vehicle alone (corn oil) $(\mathrm{C}+\mathrm{OVX}+\mathrm{V}, n=5)$, and the effects were compared against the control group submitted to $\mathrm{E} 2$ treatment $(\mathrm{C}+\mathrm{OVX}+\mathrm{E} 2)$. The treatment with the $\mathrm{E} 2$ implants produces blood levels of $\mathrm{E} 2$ that are equivalent to E2 circulating levels during the rat estrous cycle (Smith et al. 1975, Bottner \& Wuttke 2005). This was verified by measuring E2 serum levels (see 'Determination of E2 serum levels' section). After surgery, animals were allowed to recover in a clean cage under a heating lamp. Analgesia ( $2 \mathrm{mg} / \mathrm{kg}$ of flunixin meglumine, Aplonal, König, Buenos Aires, Argentina) was administered subcutaneously once per day and for 3 days, starting after capsule implantation. Once the animals were fully conscious and active, they were housed individually and daily monitored for signs of pain or distress for a period of 1 week. Female rats were killed when they were 2 months of age (PND60) to collect trunk blood and uterine tissue. Blood samples were centrifuged $(1300 \boldsymbol{g}, 20 \mathrm{~min})$ and serum was stored at $-20^{\circ} \mathrm{C}$ until hormone assay was performed. One uterine horn of each rat was fixed by immersion in 10\% buffered formalin for $6 \mathrm{~h}$ at $4^{\circ} \mathrm{C}$ and processed for histology and immunohistochemistry (IHC). The other uterine horn of each rat was immediately frozen in liquid nitrogen and stored at $-80^{\circ} \mathrm{C}$ for RNA extraction followed by reverse transcription-polymerase chain reaction (RT-PCR) assay.

\section{Determination of E2 serum levels}

Serum samples stored at $-20^{\circ} \mathrm{C}$ were thawed and E2 serum levels were assessed using the Ultra-Sensitive Estradiol Radioimmunoassay Kit DSL4800 (Immunotech, Beckman Coulter, Czech Republic) according to the manufacturer's guidelines. All samples were run in duplicate. The assay sensitivity was $2.2 \mathrm{pg} / \mathrm{mL}$. The intra-assay and interassay coefficients of variation were $\leq 8.9$ and $12.2 \%$.

\section{Histology and morphometry}

Uterine samples embedded in paraffin were longitudinally cut $(5 \mu \mathrm{m}$ thick) at three different depths (separated $50 \mu \mathrm{m}$ from each other), mounted on slides coated with 3-aminopropyl triethoxysilane (Sigma-Aldrich), stained with hematoxylin and eosin (H\&E) and examined by light microscope (Olympus $\mathrm{BH} 2$ microscope; Olympus) to analyze uterine morphology. Uterine sections were evaluated for histologic changes by a trained pathologist blinded to the experimental group. We also determined glandular density, stromal nuclei density, luminal and glandular epithelial heights and the thickness of the stroma and myometrium. To determine the glandular density, the volume fraction ( $V v)$ of uterine glands was calculated by applying the following formula given by Weibel (1969): $V v=P i / P$, where $V v$ is the estimated volume fraction of the object (glands), $P i$ is the number of incident points over the glands and $P$ is the number of incident points over all cells in the studied population (stroma). To obtain the data for this point-counting procedure, a glass disk with a squared grid of $0.8 \mathrm{~mm} \times 0.8 \mathrm{~mm}$ was inserted into a Dplan $40 \times$ focusing eyepiece (numerical aperture $=0.65$, Olympus) (Gundersen et al. 1988, Ramos et al. 2002). The results were expressed as $V v \times 100$. The $V v$ of uterine glands was quantified on at least 20 randomly selected fields per section, and three sections per animal (separated $50 \mu \mathrm{m}$ from each other) were evaluated. The stromal nuclei density was defined as the ratio between the area occupied by stromal nuclei and total subepithelial stromal area ( $150 \mu \mathrm{m}$ wide area adjacent to the epithelium, from the basement membrane toward the outer layer). Areas were quantified using Fiji of ImageJ, excluding uterine glands, infiltrating cells and blood vessel cells from analysis (Durando et al. 2007). The luminal and glandular epithelial heights, and the thickness of the stromal and myometrial (circular and longitudinal) layers 
Table 1 Primers used for qRT-PCR.

\begin{tabular}{l} 
Gene name \\
\hline Esr1 \\
Esr2 \\
Ctnnb1 \\
Wnt7a \\
Rpl19
\end{tabular}

Primer sense $\left(5^{\prime} \rightarrow 3^{\prime}\right)$
ACTACCTGGAGAACGAGCCC
TTCTGGGCACCTGTCTCCTT
GAGCACATCAGGACACCCAGC
CTTACACAATAACGAGGCAGGC
AGCCTGTGACTGTCCATTCC

Primer antisense $\left(5^{\prime} \rightarrow 3^{\prime}\right)$
CCTTGGCAGACTCCATGATC
TAACAGGGCTGGCACAACTG
GAGGATGTGGAGAGCCCCAGT
TCTCGGAATTGTGGCAGTGT
TGGCAGTACCCTTCCTCTTC

\begin{tabular}{c}
\hline Product size $(\mathrm{bp})$ \\
\hline 153 \\
166 \\
116 \\
126 \\
99
\end{tabular}

Ctnnb1, beta-catenin; Esr1, estrogen receptor alpha; Esr2, estrogen receptor beta; Rp/19, ribosomal protein L19; Wnt7a, wingless-type MMTV integration site family, member 7A.

were analyzed by image analysis using Fiji of ImageJ as previously described (Ramos et al. 2002, Varayoud et al. 2017). Briefly, the images were recorded with a Spot Insight V3.5 color video camera, attached to a microscope (Olympus). To spatially calibrate the software analyzer, square grids from Neubauer's chamber images were captured. At least five fields were recorded in each section using a Dplan 20× objective (numerical aperture $=0.40$, Olympus), and three sections per animal (separated $50 \mu \mathrm{m}$ from each other) were evaluated.

\section{Reverse transcription and real-time quantitative PCR analysis (qRT-PCR)}

\section{RNA extraction and reverse transcription}

Individual uterine horn samples from each experimental group were homogenized in TRIzol reagent (Invitrogen) and total RNA was extracted according to the manufacturer's instructions. The concentration and purity of total RNA was determined by measuring the optical density at 260 and $280 \mathrm{~nm}$. All samples were precipitated with ethanol, dissolved in distilled water, and then stored at $-80^{\circ} \mathrm{C}$ until needed. Equal quantities $(1 \mu \mathrm{g})$ of total RNA were reverse-transcribed into cDNA with Moloney Murine Leukemia Virus reverse transcriptase (MMLV-RT; 300 units; Promega) using $200 \mathrm{pmol}$ of random primers (Biodynamics, Buenos Aires, Argentina). Twenty units of ribonuclease inhibitor (RNAout, Invitrogen Argentina) and $100 \mathrm{nmol}$ of a deoxynucleotide triphosphate mixture were added to each reaction tube at a final volume of $30 \mu \mathrm{L}$ of $1 \times$ MMLV-RT buffer. Reverse transcription was performed at $37^{\circ} \mathrm{C}$ for $90 \mathrm{~min}$ and at $42^{\circ} \mathrm{C}$ for $15 \mathrm{~min}$. Reactions were stopped by heating at $80^{\circ} \mathrm{C}$ for $5 \mathrm{~min}$ and cooling on ice. Each reverse-transcribed product was diluted with RNase-free water to a final volume of $60 \mu \mathrm{L}$.

\section{qRT-PCR}

The mRNA expression levels of total Esr1, Esr2, Wnt7a, Ctnnb1 and ribosomal protein L19 (Rpl19, housekeeping gene) were quantified by qRT-PCR using the Rotor-Gene
Q cycler (Qiagen; Tecnolab). The gene-specific primer sequences are shown in Table 1 . For cDNA amplification, $5 \mu \mathrm{L}$ of cDNA were combined with HOT FIREPol EvaGreen qPCR Mix Plus (Solis BioDyne; Biocientífica, Rosario, Argentina) and $10 \mathrm{pmol}$ of each primer (Invitrogen) in a final volume of $20 \mu \mathrm{L}$. After initial denaturation at $95^{\circ} \mathrm{C}$ for $15 \mathrm{~min}$, the reaction mixture was subjected to successive cycles of denaturation at $95^{\circ} \mathrm{C}$ for $15 \mathrm{~s}$, annealing at $56-60^{\circ} \mathrm{C}$ for $15 \mathrm{~s}$ and extension at $72^{\circ} \mathrm{C}$ for $15 \mathrm{~s}$. Product purity was confirmed by dissociation curves and random samples were subjected to agarose gel electrophoresis. Controls containing no template DNA were included in all assays, yielding no consistent amplification. The cycle threshold $\left(\mathrm{C}_{\mathrm{T}}\right)$ for each sample was calculated using the Rotor-Gene Q Series Software (Version 1.7, Qiagen; Tecnolab) with an automatic fluorescence threshold setting. The efficiency of PCR reactions was assessed for each target by the amplification of serial dilutions (over five orders of magnitude) of cDNA fragments of the transcripts under analysis. Accordingly, the fold expression over control values was calculated for each target by the relative standard curve methods, which are designed to analyze data from real-time PCR (Cikos et al. 2007). For all experimental samples, the target quantity is determined from the standard curve, normalized to the quantity of the housekeeping gene and finally divided by the target quantity of the control sample. No significant differences in $\mathrm{C}_{\mathrm{T}}$ values were observed for Rpl19 among the experimental groups.

\section{Immunohistochemistry}

The protein expression of the cell proliferation marker Ki67 and the ERs (ESR1 and ESR2) was analyzed to evaluate the uterine response to exogenous E2 treatment. WNT7A and CTNNB1 protein immunostaining was evaluated as E2-modulated targets that have been implicated in altered uterine E2 responsiveness and neoplasia. A standard immunohistochemical technique was performed following protocols previously described by our laboratory 
Table 2 Antibodies used for immunohistochemistry.

\begin{tabular}{lc}
\hline Antibodies & Dilution \\
\hline Primary & \\
$\quad$ Anti-Ki67 (clone MIB-5) & $1 / 50$ \\
Anti-ESR1 (clone 6F-11) & $1 / 200$ \\
Anti-ESR2 (clone EMR02) & $1 / 50$ \\
Anti-WNT7A & $1 / 800$ \\
$\quad$ Anti- $\beta$-catenin (sc-7963) & $1 / 800$ \\
Secondary & $1 / 100$ \\
Anti-mouse (B8774) & $1 / 200$ \\
Anti-rabbit (B8895) & \\
\hline
\end{tabular}

Supplier

Dako

Novocastra (Newcastle upon Tyne, UK)

Novocastra (Newcastle upon Tyne, UK)

Generated and validated in our laboratory (Vigezzi et al. 2016) Santa Cruz Biotechnology

Sigma-Aldrich

Sigma-Aldrich

ESR1, estrogen receptor alpha; ESR2, estrogen receptor beta; WNT7A, wingless-type MMTV integration site family, member 7A.

(Muñoz-de-Toro et al. 1998). Briefly, uterine longitudinal sections (5 $\mu \mathrm{m}$ thick) were deparaffinized and rehydrated in graded ethanol solutions. After microwave pretreatment for antigen retrieval, the endogenous peroxidase activity and non-specific binding sites were blocked. Samples were incubated in a humid chamber with the specific primary antibody (overnight at $4^{\circ} \mathrm{C}$ ) and then with the corresponding biotin-conjugated secondary antibody (30 min at room temperature) (described in Table 2). Reactions were developed using the avidin-biotinperoxidase method and diaminobenzidine (Sigma-Aldrich) as a chromogen substrate. Each immunohistochemical run included negative controls in which the primary antibody was replaced by non-immune horse serum (Sigma-Aldrich). For Ki67 immunodetection, samples were counterstained with Mayer's hematoxylin (Biopur, Rosario, Argentina). Samples were dehydrated and mounted with permanent mounting medium (Eukitt, Sigma-Aldrich).

\section{Quantification of cell proliferation}

Tissue sections (three per animal, separated $50 \mu \mathrm{m}$ from each other) were evaluated using the Olympus BH2 microscope with the Dplan $40 \times$ objective (numerical aperture $=0.65$; Olympus). The proliferation rate was assessed in the luminal and glandular epithelium as a percentage of Ki67-positive cells on a total of 2000 cells per compartment in each uterine section. In the subepithelial stroma, the proliferation rate was obtained considering the $V v$ of the Ki67-positive cells, as previously described in 'Histology and morphometry' section of 'Materials and methods'.

\section{Quantification of protein expression by image analysis}

The protein expression of the ERs (ESR1 and ESR2), WNT7A and CTNNB1 in uterine cells was evaluated by

$\begin{array}{lr}\text { https://joe.bioscientifica.com } & \text { (c) } 2018 \text { Society for Endocrinology } \\ \text { https://doi.org/10.1530/JOE-18-0207 } & \text { Published by Bioscientifica Ltd. } \\ \text { Printed in Great Britain }\end{array}$

image analysis, using Fiji of Image J as previously described (Ramos et al. 2002). In brief, immunostained images were captured with a Dplan $40 \times$ objective (numerical aperture $=0.65$; Olympus) attached to a Spot Insight V3.5 color video camera. After conversion of each image into a gray scale, the integrated optical density (IOD) was measured as a linear combination of the average gray intensity and the relative area occupied by the positive cells (Ramos et al. 2001, 2002). Because the IOD is a dimensionless parameter, the results were expressed as arbitrary units. Protein quantification was performed in duplicate in the luminal and glandular epithelium, and in the subepithelial stroma $(150-\mu \mathrm{m}$-wide area adjacent to the epithelium, from the basement membrane toward the outer layer) on two uterine sections, separated $50 \mu \mathrm{m}$ from each other. Moreover, in each uterine section quantification was performed on at least 10 randomly selected fields.

\section{Statistical analysis}

Results are expressed as the mean \pm s.e.M. All data were analyzed using a Mann-Whitney $U$ test (GraphPad Prism, version 5.03). Values with $P<0.05$ were accepted as significant.

\section{Results}

\section{Estradiol serum levels}

In order to know the serum levels of $17 \beta$-estradiol reached by E2 implants, the concentration of E2 was measured in the serum of $\mathrm{C}+\mathrm{OVX}+\mathrm{V}, \mathrm{C}+\mathrm{OVX}+\mathrm{E} 2$ and $\mathrm{GBH}+\mathrm{OVX}+\mathrm{E} 2$ female rats. As expected, E2 serum levels were below the detection limit of the assay in OVX rats treated with vehicle $(\mathrm{C}+\mathrm{OVX}+\mathrm{V}$ group). In $\mathrm{C}+\mathrm{OVX}+\mathrm{E} 2$ females, E2 implants raised E2 serum concentrations to around $30 \mathrm{pg} / \mathrm{mL}$. No differences were observed in 
Table 3 Serum levels of $17 \beta$-estradiol (E2).

\begin{tabular}{lc}
\hline Treatment group & E2 levels $(\mathrm{pg} / \mathrm{mL})$ \\
\hline $\mathrm{C}+\mathrm{OVX}+\mathrm{V}$ & $\mathrm{ND}$ \\
$\mathrm{C}+\mathrm{OVX}+\mathrm{E} 2$ & $33.1 \pm 3.3$ \\
$\mathrm{GBH}+\mathrm{OVX}+\mathrm{E} 2$ & $31.6 \pm 2.0$
\end{tabular}

Estradiol levels were measured via RIA. Values are mean \pm s.E.M. ( $n=5-8$ rats/group).

C, control; E2, $17 \beta$-estradiol (1 mg/mL); GBH, glyphosate-based herbicide (2 mg of glyphosate/kg bw/day); ND, not detected; OVX, ovariectomized; $\mathrm{V}$, vehicle.

control and postnatally GBH-exposed animals treated with E2 (C+OVX+E2: $33.1 \pm 3.3 \mathrm{pg} / \mathrm{mL} ; \mathrm{GBH}+\mathrm{OVX}+\mathrm{E} 2$ : $31.6 \pm 2.0 \mathrm{pg} / \mathrm{mL}, P=0.90$ ) (Table 3 ).

\section{Characterization of uterine responses to E2 treatment}

Our first aim was to characterize the uterine response to estrogenic treatment between $\mathrm{C}+\mathrm{OVX}+\mathrm{V}$ and $\mathrm{C}+\mathrm{OVX}+\mathrm{E} 2$ by comparing uterine morphology, cell proliferation and the expression of both ESR1 and ESR2. As expected, uterine morphology was clearly different between vehicle- and E2-stimulated rats. The larger longitudinal section area of the E2-exposed uteri was evident at low magnification (Fig. $2 \mathrm{~A}$ vs B). Uteri from $\mathrm{C}+\mathrm{OVX}+\mathrm{V}$ females revealed an atrophic endometrium with simple

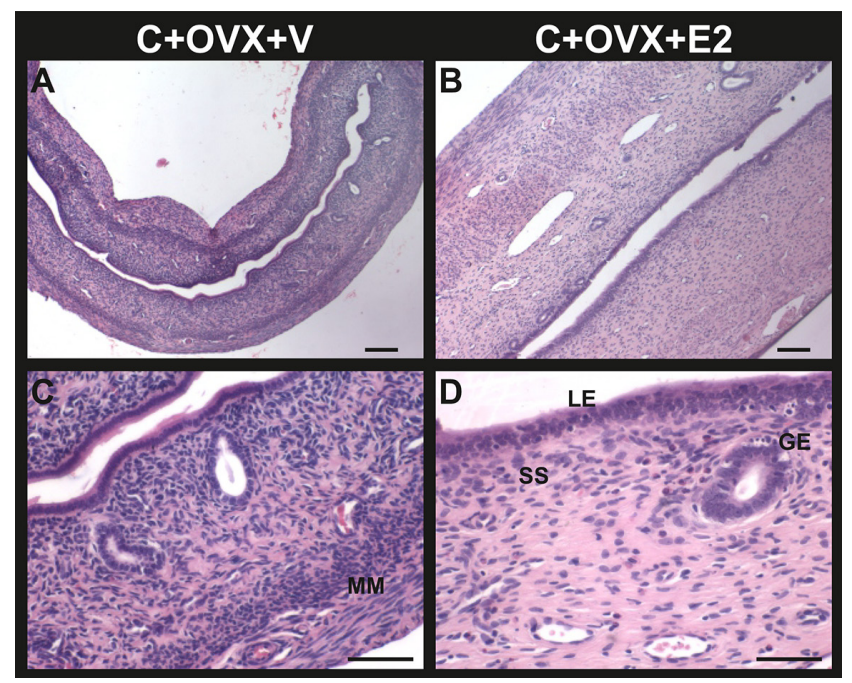

\section{Figure 2}

Uterine histology in OVX prepubertal control rats following vehicle treatment $(\mathrm{C}+\mathrm{OVX}+\mathrm{V})$ or E2 stimulation $(\mathrm{C}+\mathrm{OVX}+\mathrm{E} 2)$. Representative images of longitudinal sections of uterine horns of $\mathrm{C}+\mathrm{OVX}+\mathrm{V}$ and $\mathrm{C}+\mathrm{OVX}+\mathrm{E} 2$ animals stained with $\mathrm{H} \& \mathrm{E}$ at low $(\mathrm{A}$ and $\mathrm{B})$ and high ( $\mathrm{C}$ and $\mathrm{D})$ magnification. GE, glandular epithelium; LE, luminal epithelium; MM, myometrium; SS, subepithelial stroma. Scale bar: (A and B) $100 \mu \mathrm{m}$; (C and D) $50 \mu \mathrm{m}$. A full colour version of this figure is available at https://doi. org/10.1530/JOE-18-0207. cuboidal epithelium in the lumen and glands as well as densely-packed stromal cells (Fig. 2C). In contrast, the luminal epithelium in E2-exposed uteri $(\mathrm{C}+\mathrm{OVX}+\mathrm{E} 2$ group) was hypertrophic (pseudostratified columnar cells) to low-grade hyperplastic. Additionally, the subepithelial stroma showed signs of water imbibition and was heavily infiltrated by inflammatory leukocytes (Fig. 2D).

Uterine response to $\mathrm{E} 2$ involves the differential modulation of the ERs and changes in cell proliferation. In our model of exposure, E2 administration resulted in downregulation of Esr1 mRNA levels (Fig. 3A; $P<0.05$ ) and upregulation of the Esr 2 mRNA levels (Fig. 3B; $P<0.05$ ). Immunohistochemical analysis of protein expression showed that E2-treated animals exhibited downregulation of ESR1 (Fig. 3C, D vs E; $P<0.05$ ) and upregulation of ESR2 (Fig. 3C, F vs $G ; P<0.05$ ) in all uterine regions evaluated. In addition, a dramatic increase in cell proliferation in both luminal and glandular epithelial cells was detected after E2 treatment (Fig. 3C, H vs I; $P<0.01$ ).

\section{Long-lasting effects of GBH on uterine sensitivity to E2}

\section{Uterine histomorphology}

Histological features of uterine sections are illustrated in Fig. 4. As previously mentioned, E2 stimulation prompted hypertrophy (pseudostratified columnar cells) and low-grade hyperplasia in the uterine luminal epithelium (C+OVX+E2 group) (Fig. 4A and D). We observed that uteri of female rats postnatally exposed to $\mathrm{GBH}$ and treated with E2 (GBH+OVX+E2 group) showed histomorphological alterations. In fact, the luminal and glandular epithelium were markedly hyperplastic (43\% of animals). GBH+OVX+E2 rats showed areas of endometrium with stratification of the luminal epithelium, hypochromic nuclei and mitotic figures (Fig. 4B and E). Furthermore, in GBH-exposed uteri treated with E2, several abnormal glands were observed that contained cells that were morphologically similar to those of the luminal epithelium (Fig. 4C and F). In addition, GBH-exposed animals showed increased luminal epithelial height and stromal nuclei density (Table 4). The evaluation of other morphological parameters did not show differences between control and postnatally GBHexposed animals (C+OVX+E2 vs GBH+OVX+E2) (Table 4).

\section{Uterine proliferation}

Evaluation of cell proliferation was performed by the assessment of Ki67 expression. An increased proliferative response to $\mathrm{E} 2$ treatment was detected in the postnatally 

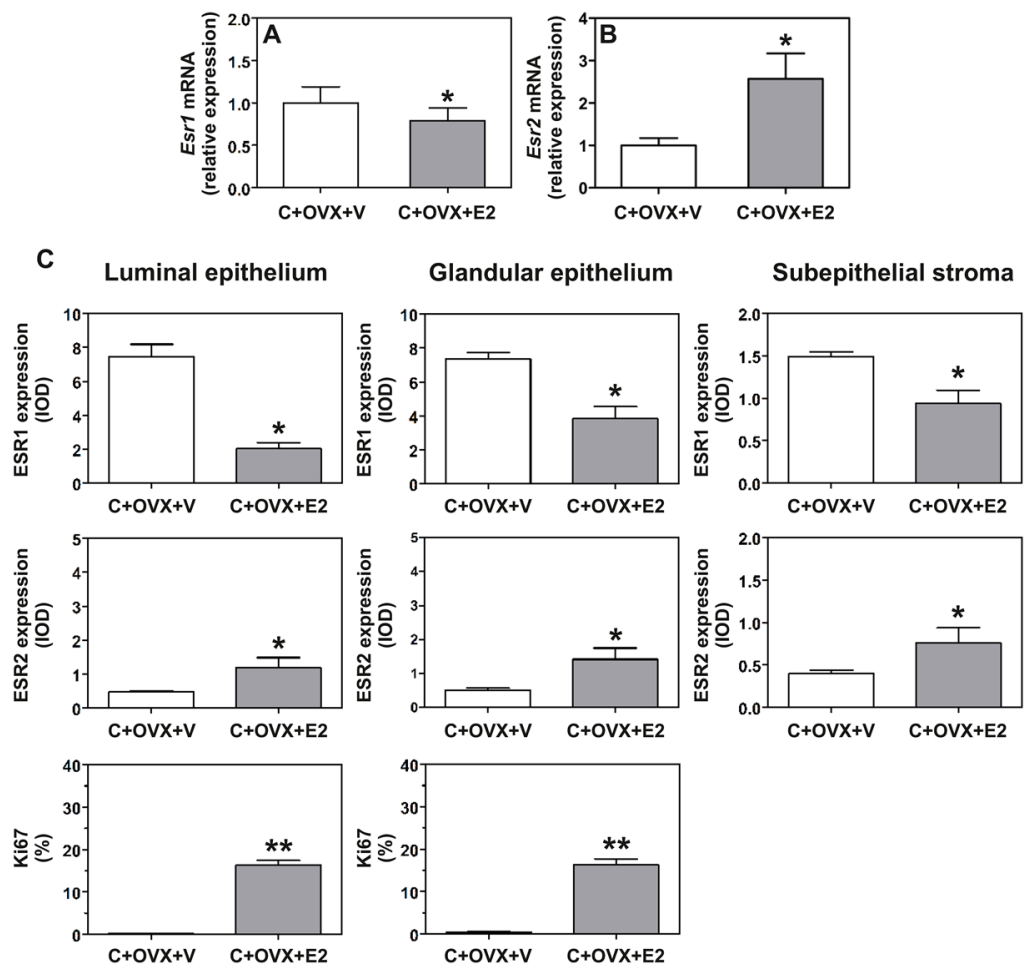

$C+O V X+V \quad C+O V X+E 2$

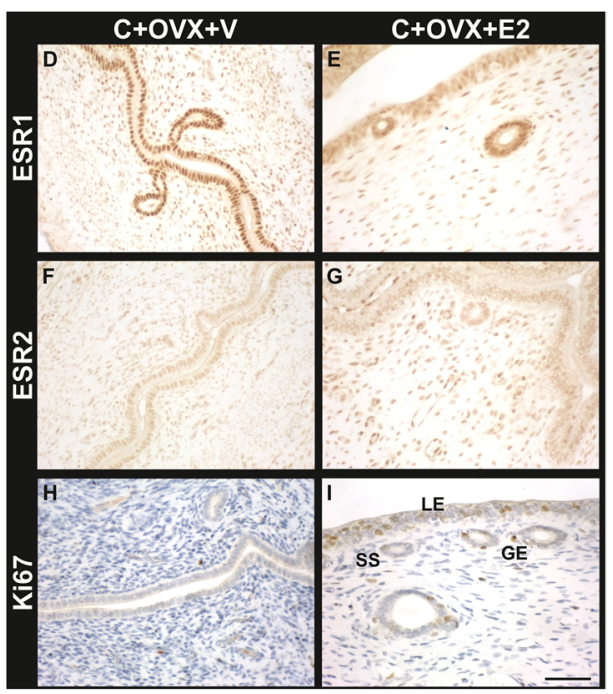

Figure 3

Uterine responsiveness to E2 stimulation in OVX prepubertal rats: expression of the estrogen receptors alpha (ESR1) and beta (ESR2), and cell proliferation. ( $A$ and $B)$ Relative mRNA levels of Esr1 and Esr2 in vehicle- $(C+O V X+V)$ and E2-treated $(C+O V X+E 2)$ animals were measured by qRT-PCR. Fold expression from $\mathrm{C}+\mathrm{OVX}+\mathrm{V}$ values was calculated by the relative standard curve method. $\mathrm{C}+\mathrm{OVX}+\mathrm{V}$ values were assigned to a reference level of 1 and values are given as mean \pm S.E.M. of two independent determinations. Significant effects are depicted with asterisks ( $\left.{ }^{2}<0.05\right)$. (C) Quantification of ESR1 and ESR2 protein immunostaining is expressed as the integrated optical density (IOD). Cell proliferation is shown as a percentage of Ki67-positive cells. Significant effects are depicted with asterisks ( $\left.{ }^{*} P<0.05 ; * * P<0.01\right) .(D, E, F, G, H$ and I) Representative images of protein expression of the ESR1 (D and E) and ESR2 ( $F$ and $G)$, and cellular proliferative responses by Ki67 immunodetection ( $\mathrm{H}$ and $\mathrm{I})$ in $\mathrm{C}+\mathrm{OVX}+\mathrm{V}$ and $\mathrm{C}+\mathrm{OVX}+\mathrm{E} 2 \mathrm{groups}$. GE, glandular epithelium; LE, luminal epithelium; SS, subepithelial stroma. Scale bar: $50 \mu \mathrm{m}$. A full colour version of this figure is available at https://doi.org/10.1530/JOE-18-0207.

GBH-exposed uteri. The evaluation of cell proliferation in the luminal epithelial compartment indicated that in $\mathrm{GBH}+\mathrm{OVX}+\mathrm{E} 2$ females the Ki67 expression was higher $(29.07 \pm 3.89 \%, P<0.05)$ than in the $\mathrm{C}+\mathrm{OVX}+\mathrm{E} 2$ group
(16.36 $\pm 1.10 \%)$ (Fig. 5A). Photomicrographs illustrating these results are shown in Fig. 5B. Glandular epithelial cells showed similar changes, but the induction of cell proliferation was not different between control

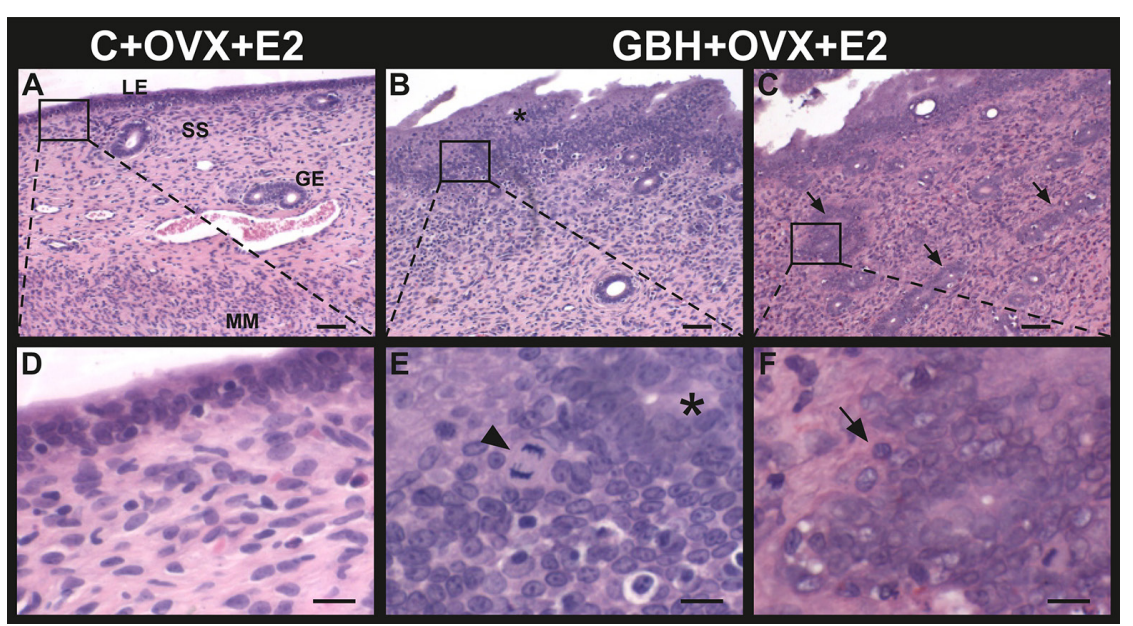

Figure 4

Uterine histological lesions in postnatally GBH-exposed animals after E2 stimulation at low and high magnification. (A and D) Normal uterine histology in OVX control rats after E2 treatment (C+OVX+E2). (B, C, E and F) Representative H\&E stained images of postnatally $\mathrm{GBH}$-exposed rats after E2 stimulation ( $\mathrm{GBH}+\mathrm{OVX}+\mathrm{E} 2)$ demonstrating histological findings. Abnormal endometrial glands (arrows) and areas of endometrium with stratification of the luminal epithelium (asterisk), hypochromic nuclei (asterisk) and mitotic figures (arrowheads) are indicated. Uterine areas in the insets are magnified in the lower panel. GE, glandular epithelium; LE, luminal epithelium; MM, myometrium; SS, subepithelial stroma. Scale bar: (A, B and C) $50 \mu \mathrm{m} ;(\mathrm{D}, \mathrm{E}$ and F) $10 \mu \mathrm{m}$. A full colour version of this figure is available at https://doi.org/10.1530/JOE-18-0207.

https://joe.bioscientifica.com https://doi.org/10.1530/JOE-18-0207 (c) 2018 Society for Endocrinology Published by Bioscientifica Ltd. Printed in Great Britain 
Table 4 Morphometric analysis of uterine sections.

\section{Parameters}

Luminal epithelial height $(\mu \mathrm{m})$

Glandular epithelial height $(\mu \mathrm{m})$

Endometrial glands $(V v \times 100)$

Stromal nuclei density (\%)

Stromal thickness $(\mu \mathrm{m})$

Circular myometrium thickness $(\mu \mathrm{m})$

Longitudinal myometrium thickness $(\mu \mathrm{m})$

C+OVX+E2
$32.04 \pm 4.03$
$15.30 \pm 1.34$
$4.63 \pm 0.21$
$19.99 \pm 0.97$
$571.25 \pm 39.44$
$159.42 \pm 13.85$
$139.89 \pm 12.63$

\begin{tabular}{c}
\hline GBH+OVX+E2 \\
$68.10 \pm 13.76^{*}$ \\
$15.42 \pm 1.16$ \\
$5.26 \pm 0.40$ \\
$26.04 \pm 1.67 * *$ \\
$598.12 \pm 42.88$ \\
$198.78 \pm 26.48$ \\
$173.33 \pm 16.69$ \\
\hline
\end{tabular}

Values are means \pm S.E.M. ( $n=7-8$ rats/group).

${ }^{*} P<0.05,{ }^{*} P<0.01$ compared with the control group.

C, control; E2, $17 \beta$-estradiol (1 mg/mL); GBH, glyphosate-based herbicide ( $2 \mathrm{mg}$ of glyphosate/kg b.w/day); OVX, ovariectomized; $V v$, volume fraction.

and GBH-exposed females (C+OVX+E2: $16.32 \pm 1.42 \%$; $\mathrm{GBH}+\mathrm{OVX}+\mathrm{E} 2: 20.16 \pm 3.42 \%, P=0.62$ ) (Fig. 5A). Finally, the stromal cell proliferation was very low showing no changes between $\mathrm{C}+\mathrm{OVX}+\mathrm{E} 2-$ and $\mathrm{GBH}+\mathrm{OVX}+\mathrm{E} 2$-treated animals (data not shown).

\section{Expression of the estrogen receptors}

Uterine expression of the ESR1 and ESR2 in control and GBH-exposed animals that received E2 treatment was evaluated at mRNA and protein levels. As previously mentioned, E2 stimulation induced downregulation of Esr1 mRNA (C+OVX+E2 vs $\mathrm{C}+\mathrm{OVX}+\mathrm{V}$ rats, Fig. 3A). We found that when rats were postnatally exposed to $\mathrm{GBH}$, the Esr1 mRNA downregulation was accentuated (Fig. 6A; $P<0.05)$. Likewise, the induction of Esr2 mRNA detected in $\mathrm{C}+\mathrm{OVX}+\mathrm{E} 2$ animals was enhanced in the uteri from $\mathrm{GBH}+\mathrm{OVX}+\mathrm{E} 2$ group (Fig. $6 \mathrm{~B} ; \mathrm{P}<0.05$ ). A similar response was detected when we analyzed the protein expression of ESR2. Postnatal exposure to GBH enhanced the ESR2 increase caused by $\mathrm{E} 2$ treatment in all uterine regions evaluated (luminal, glandular and stromal) (Fig. 6C; $P<0.05)$. For ESR1, a strong induction was detected in the luminal epithelial cells of GBH-exposed animals (Fig. 6C, $P<0.05$ ), without changes in the subepithelial stroma or the glandular epithelium. Based on microscopic examination, increased levels of epithelial ESR1 expression were related not only to an increase in cell number but also to changes in expression levels within cells (the intensity of immunostaining). Representative images illustrating these results are shown in Fig. 6D.
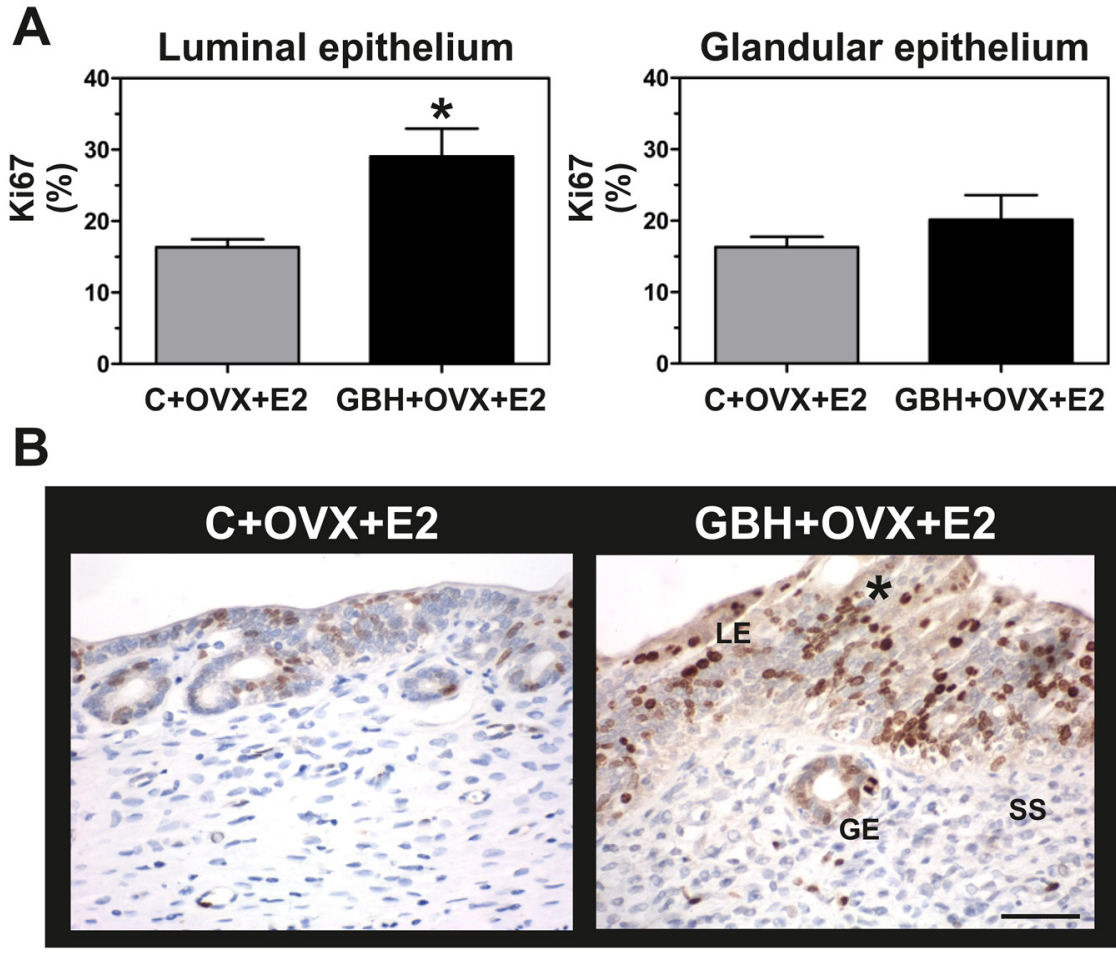

\section{Figure 5}

Effects of GBH postnatal exposure on E2-induced cell proliferation. (A) Ki67 protein expression was quantified in luminal and glandular epithelial uterine cells. Values in bar graphs are the mean \pm S.E.M. The asterisk indicates statistical significance compared with the control $\left({ }^{*} P<0.05\right)$. (B) Representative images of immunohistochemical detection of $\mathrm{Ki67}$ on uterine sections. The asterisk indicates the increase of Ki67 expression. GE, glandular epithelium; LE, luminal epithelium; SS, subepithelial stroma. Scale bar: $50 \mu \mathrm{m}$. A full colour version of this figure is available at https:// doi.org/10.1530/JOE-18-0207. https://joe.bioscientifica.com https://doi.org/10.1530/JOE-18-0207
(C) 2018 Society for Endocrinology Published by Bioscientifica Ltd. Printed in Great Britain 


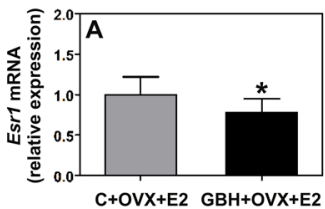

$\mathrm{C}+\mathrm{OVX}+\mathrm{E} 2 \quad \mathrm{GBH}+\mathrm{OVX}+\mathrm{E} 2$

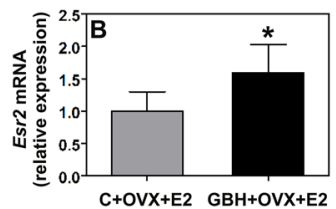

$\mathrm{C}+\mathrm{OVX}+\mathrm{E} 2 \quad \mathrm{GBH}+\mathrm{OVX}+\mathrm{E} 2$

C Luminal epithelium

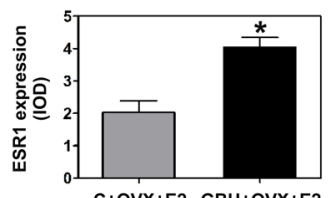

$\mathrm{C}+\mathrm{OVX}+\mathrm{E} 2 \quad \mathrm{GBH}+\mathrm{OVX}+\mathrm{E} 2$
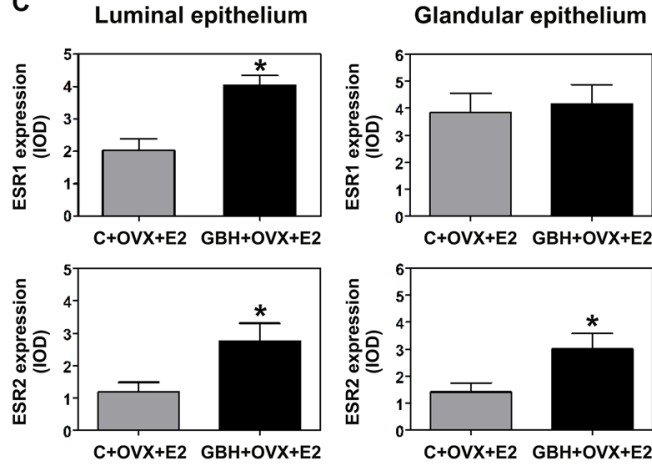

C+OVX+E2 GBH+OVX+E
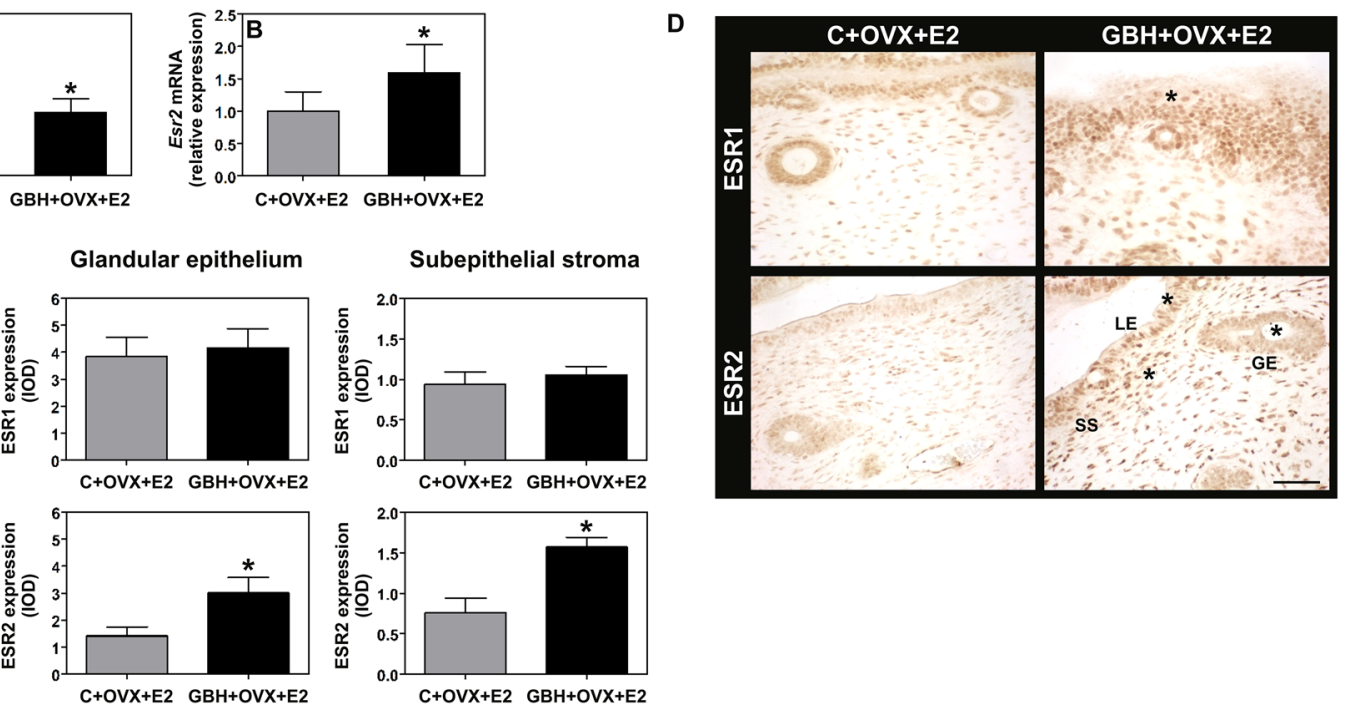

Figure 6

Effects of GBH postnatal exposure on uterine expression of the estrogen receptors alpha (ESR1) and beta (ESR2). (A and B) Relative mRNA levels of Esr1 (A) and Esr2 (B) in control and postnatally GBH-exposed animals were measured by qRT-PCR. Fold expression from $\mathrm{C}+\mathrm{OVX}+\mathrm{E} 2$ values was calculated by the relative standard curve method. $\mathrm{C}+\mathrm{OVX}+\mathrm{E} 2$ values were assigned to a reference level of 1 and values are given as mean \pm S.E.M. of two independent determinations. Significant effects are depicted with asterisks ( $*<0.05$ ). (C) Quantification of ESR1 and ESR2 protein immunostaining in uterine regions is expressed as the integrated optical density (IOD). Values in bar graphs are the mean \pm s.E.M. Asterisks indicate statistical significance compared with the control ( $\left.{ }^{*} P<0.05\right)$. (D) Representative images of immunohistochemical staining for ESR1 and ESR2 on uterine sections. Significant effects are depicted with asterisks. GE, glandular epithelium; LE, luminal epithelium; SS, subepithelial stroma. Scale bar: $50 \mu \mathrm{m}$. A full colour version of this figure is available at https://doi.org/10.1530/JOE-18-0207.

\section{Expression of E2-modulated targets that have been implicated in altered uterine E2 responsiveness and neoplasia}

Uterine expression of WNT7A and CTNNB1 in control and GBH-exposed animals that received E2 treatment was evaluated at mRNA and protein levels. Treatment with $\mathrm{GBH}$ increased the expression of Wnt7a mRNA relative to control rats (Fig. $7 \mathrm{~A} ; P<0.05$ ), while induced downregulation of Ctnnb1 mRNA levels (Fig. 7B; $P<0.05$ ). Considering the differential role of these molecules according to their subcellular localization, we evaluated the spatial pattern of WNT7A and CTNNB1 expression in uteri of control and GBH-exposed rats by IHC. Both groups displayed similar expression patterns. WNT7A showed nuclear expression in the subepithelial stroma, and nuclear and cytoplasmic expression in uterine epithelial (luminal and glandular) cells. CTNNB1 displayed membranous and cytoplasmic pattern in the luminal and glandular epithelium with negative immunoreaction in the stroma. Despite no changes in the spatial pattern of WNT7A and CTNNB1 were observed, differences in immunostaining intensity were found between the experimental groups. Female rats postnatally exposed to GBH exhibited induction of WNT7A in the luminal epithelium (Fig. 7C; $P<0.05)$. Surprisingly, CTNNB1 expression was notably decreased in the luminal and glandular epithelium of GBH-treated animals (Fig. 7C; $P<0.05$ ). Representative images illustrating these results are shown in Fig. 7D.

\section{Discussion}

Prior data obtained from siblings of the animals used in the present study revealed that the exposure to low dose $(2 \mathrm{mg} / \mathrm{kgbw} /$ day) of a GBH during the first week of life resulted in alterations of uterine organogenetic and functional differentiation that caused subfertility later in life. In this line, GBH exposure elicited endometrial hyperplasia in prepubertal rats together with increased cell proliferation and altered expression of proteins involved in uterine organogenetic differentiation (Guerrero Schimpf et al. 2017). Long-term uterine effects included alterations in endocrine-dependent mechanisms involved in decidualization that leaded to post-implantation embryo loss. These alterations encompassed a dysregulation of ESR1-PR signaling (Ingaramo et al. 2016) and Wnt pathways (Ingaramo et al. 2017).

In the present study, we used a model in which animals were OVX on PND21 (prepubertal period). We hypothesized that GBH exposure during early stage 

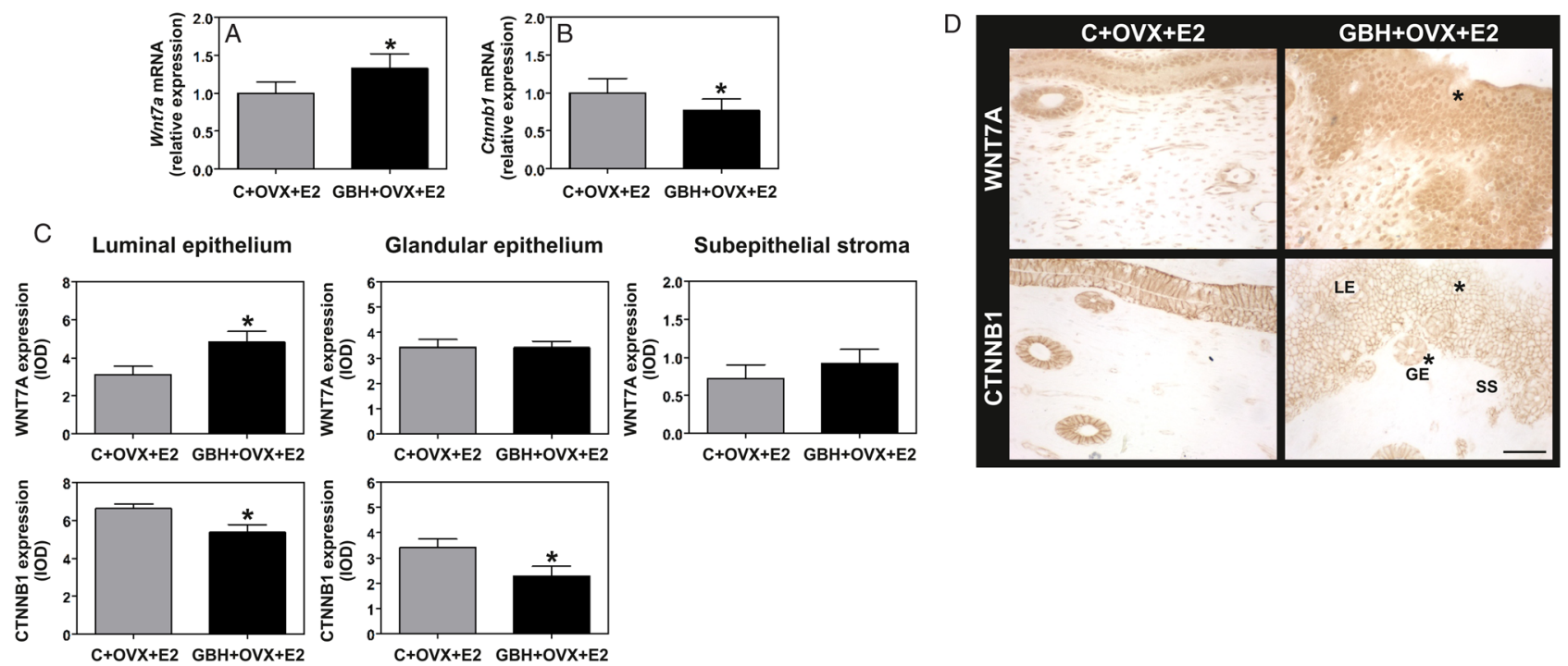

Figure 7

Effects of GBH postnatal exposure on the expression of E2-modulated targets that have been implicated in altered uterine E2 responsiveness and neoplasia. (A and B) Relative mRNA levels of Wnt7a (A) and Ctnnb1 (B) in control and postnatally GBH-exposed animals were measured by qRT-PCR. Fold expression from $\mathrm{C}+\mathrm{OVX}+\mathrm{E} 2$ values was calculated by the relative standard curve method. $\mathrm{C}+\mathrm{OVX}+\mathrm{E} 2$ values were assigned to a reference level of 1 and values are given as mean \pm S.E.M. of two independent determinations. Significant effects are depicted with asterisks (*P<0.05). (C) Quantification of WNT7A and CTNNB1 protein immunostaining in uterine regions is expressed as the integrated optical density (IOD). Values in bar graphs are the mean \pm S.E.M. Significant effects are depicted with asterisks $(* P<0.05)$. (D) Representative images of immunohistochemical staining for WNT7A and CTNNB1 on uterine sections. Significant effects are depicted with asterisks. GE, glandular epithelium; LE, luminal epithelium; SS, subepithelial stroma. Scale bar: $50 \mu \mathrm{m}$. A full colour version of this figure is available at https://doi.org/10.1530/JOE-18-0207.

of development might enhance the sensitivity of the rat uterus to E2. To test this hypothesis, different endpoints were evaluated to determine the long-term uterine response to E2: (i) uterine morphology, (ii) uterine cell proliferation, (iii) the expression of ESR1 and ESR2 and (iv) the expression of WNT7A and CTNNB1, selected as E2-modulated targets that have been implicated in altered uterine $\mathrm{E} 2$ responsiveness and neoplasia.

The uterine responsiveness to E2 stimulation in OVX rodents has been extensively studied using different models. We chose chronic E2 treatment since it has been shown that prolonged E2 stimulation plays an important role in the development of endometrial pathologies such as hyperplasia and carcinoma (Chuffa et al. 2017). In this model, serum concentrations of E2 in E2-implanted rats were equivalent to circulating levels during the rat estrous cycle (Smith et al. 1975). No differences in E2 serum levels between control and GBH-exposed rats were detected, indicating that all animals were exposed to the same levels of E2. Some studies have shown that GBH exposure can disrupt aromatase (Richard et al. 2005, Cassault-Meyer et al. 2014, Defarge et al. 2016), the key enzyme responsible for the conversion of androgens into estrogens. It is worth noting here that, since we worked with OVX rats that received exogenous E2 treatment, the contribution of extragonadal aromatization to E2 serum levels would be negligible. However, taking into account that aromatase is an estrogen-sensitive gene and is related to uterine disorders (Bulun et al. 2005), we cannot discard that aromatase expression could be affected in GBH-exposed animals.

Using this model, we detected that when OVX animals were chronically exposed to E2, uterine histomorphology showed signs of higher sensitivity to $\mathrm{E} 2$ in the postnatally GBH-treated group. The results showed that the luminal and glandular epithelium were markedly hyperplastic. Different morphological changes were detected in GBH-exposed animal, such as increase of luminal epithelial height and higher stromal nuclei density, both histological features of simple endometrial hyperplasia (Dixon et al. 2014, Sanderson et al. 2017). Similar alterations in both uterine regions were observed at the neonatal period (PND8) (Guerrero Schimpf et al. 2017), suggesting that GBH exposure permanently alters uterine histoarchitecture. Interestingly, DES-exposed mice and hamsters that exhibited endometrial hyperplasia (Hendry et al. 1997, Yamashita 2006) developed uterine adenocarcinoma later in life (Leavitt et al. 1981, Newbold et al. 1990). Considering that endometrial hyperplasia has the potential to progress to endometrial cancer (Mutter et al. 2007, Sanderson et al. 2017), our present findings 
provide the first evidence of a link between developmental exposure to GBH and uterine development of preneoplastic lesions after prolonged E2 exposure.

In addition, we observed a dramatic increase in uterine epithelial cell proliferation in association with a strong induction of ESR1 in postnatally GBH-exposed females. ESR1 plays a crucial role in uterine cell proliferation stimulated by E2. In vivo studies have demonstrated that both stromal and epithelial ESR1 expression is important to induce uterine proliferation and epithelial cell growth. Winuthayanon et al. (2014) have shown that epithelial ESR1 is essential for long-term uterine responsiveness to E2. Its expression induces gene products involved in mitosis and cell cycle progression as well as inhibition of apoptosis. These authors suggest that epithelial ESR1 may generate autocrine signals or provide a positive feedback to stromal cells to stimulate epithelial cell proliferation (Winuthayanon et al. 2010, 2014). Hence, the epithelial hyperplasia of GBH-exposed animals could be attributed, at least in part, to an increased expression of epithelial ESR1 that generates a maximal mitogenic signal. Moreover, our results are in concordance with the findings of Tica et al. (2016) who showed that ESR1 expression is increased in normal proliferative and benign hyperplastic epithelial cells. It is worth noting the differences in responsiveness to estrogens in relation to proliferative activity between luminal and glandular epithelial cells. In fact, luminal epithelial cells in GBHexposed animals were more sensitive to E2-induced cell proliferation. Taking into account the important role of ESR1 over cell proliferation control, higher luminal epithelial proliferation might be related to higher ESR1 expression in this compartment. Contrary, in the glandular epithelium neither proliferation nor ESR1 expression were affected.

As previously mentioned, in our model of exposure, E2 administration induced downregulation of Esr 1 mRNA levels. In addition, GBH-exposed animals showed decreased expression of Esr1 mRNA. However, a similar decrease in ESR1 protein expression was not observed. In fact, GBH treatment increased ESR1 in the luminal epithelium. In this context, we propose that GBH could affect protein turnover due to lower activity of the ubiquitin-proteasome pathway. It has been reported that proteasome-mediated proteolysis modulates the cellular concentration of ESR1 in a process that requires ligand binding to the receptor (Preisler-Mashek et al. 2002). Moreover, it has been demonstrated that the extent to which the overall ESR1 levels are affected depends on the ligand and is not related to ligand-binding affinity or activation of transcription (Preisler-Mashek et al. 2002).

ESR2 is important for differentiation and growth of the uterine epithelium. In addition, loss of ESR2 function results in an enhanced uterine responsiveness to E2 in the neonatal and adult uterus, highlighting its role in the inhibition of epithelial cell proliferation (Wada-Hiraike et al. 2006, Nakajima et al. 2015). Besides this protective action in normal endometrial tissue, a completely different role has been proposed in benign and malignant proliferative endometrial pathologies. Increased levels of ESR2 found in high-grade and advanced stage endometrial carcinomas as well as in endometriotic stromal cells suggest an involvement in aberrant cell proliferation and tumor-promoting activity (Bulun et al. 2010, Hapangama et al. 2015). Here, we found an increase in ESR2 uterine expression at mRNA and protein levels in GBH-exposed uteri after E2 administration. These results support the concept that alterations in ESR2 expression are important in the development and progression of uterine proliferative lesions.

In the endometrium, WNT/CTNNB1 signaling pathway is implicated in different processes such as uterine development and epithelial cell proliferation in response to E2 (Van der Horst et al. 2012). CTNNB1 plays a dual role as an adhesion molecule in adherens junctions at the plasma membrane and as a key intermediate in the canonical Wnt signaling pathway (Brembeck et al. 2006). WNT7A is a member of the Wnt protein family that is able to directly stimulate canonical Wnt signaling. We were interested in examining WNT7A expression because previous studies have shown that this protein is upregulated by E2 (Wang et al. 2010) and overexpressed in uterine disorders such as endometriosis and endometrial cancer (Gaetje et al. 2007, Liu et al. 2013). In our model, GBH treatment increased WNT7A mRNA and protein expression in the luminal epithelium, suggesting enhanced WNT/CTNNB1 signaling. However, the pattern of changes in CTNNB1 differed from those in WNT7A expression. Decreased membranous and cytoplasmic CTNNB1 expression without nuclear immunoreaction was detected in the luminal and glandular epithelium of GBHexposed rats. In accordance with these results, decreased CTNNB1 expression was observed in epithelial cells from hyperplastic uterine lesions in mice treated whit lithium and E2 (Gunin et al. 2004). Despite nuclear CTNNB1 accumulation is a well-known alteration in uterine hyperplasia and neoplasia, it has been demonstrated that CTNNB1 cell membrane expression is decreased in these types of lesions (Saegusa et al. 2001, Florescu et al. 2016). 
Loss of CTNNB1 expression on the cell surface destabilizes and weakens cell-cell adhesion favoring cell dissociation (Guarino et al. 2007). Taking into account morphologic changes induced by GBH exposure, alterations in intercellular contacts and continuous activation of WNT/CTNNB1 signaling pathway may contribute to the development of endometrial cancer.

Few studies have shown that glyphosate and its formulations can interact with the ERs. Gasnier et al. (2009) showed inhibition of ESR1 and ESR2 transcriptional activities by different GBH formulations in human liver HepG2 cells transfected with an estrogen response element construct and the ERs. On the contrary, other studies showed that glyphosate (the active ingredient of formulations) promotes cell proliferation in hormone-dependent breast cancer cells by activating the ESR1 (Thongprakaisang et al. 2013, Mesnage et al. 2017). Similarly, we and other authors have shown that glyphosate and GBHs can modulate the expression of both ER subtypes in the rat uterus (Varayoud etal.2017) as well as induce ESR1 and ESR2 protein expression in T47D breast cancer cells (Thongprakaisang et al. 2013). In the present study, we observed that postnatal exposure to GBH enhanced ESR1 and ESR2 expression in the rat uterus after E2 treatment. However, we found some differences in the expression pattern of both ERs at mRNA level. The results indicate different sensitivity between Esr1 and Esr2 in response to GBH exposure. While downregulation of Esr1 caused by GBH exposure was similar from that induced by E2 treatment alone, the enhancement of Esr2 with GBH was lower than E2 treatment alone. Similar to our findings, other study showed that the expression of both ERs in human breast cancer cells in vitro was differentially modulated after glyphosate treatment (Thongprakaisang et al. 2013). Taken together, the above-mentioned results contribute to a growing body of evidence supporting the potential interaction of GBHs with the estrogen signaling pathways.

In the last years, one matter of concern has focused on toxicological properties of chemicals used in commercial formulations of GBHs. GBHs are commercialized in the form of mixtures consisting of glyphosate (active principle) and different co-formulants (i.e. solvents, penetrating agents, preservatives, surfactants) whose identity is frequently undisclosed because it is considered to be confidential commercial information. Several studies comparing GBHs, co-formulants and glyphosate effects have revealed that GBHs are more toxic than the active ingredient, suggesting that co-formulants can also be a source of toxicity (Defarge et al. 2016, Mesnage \& Antoniou 2018). Considering these points, under the condition of our experiment, we cannot ascribe the increased uterine sensitivity to $\mathrm{E} 2$ only to glyphosate, to co-formulants or both acting together. Further research is required to fully understand glyphosate and co-formulants contribution to GBHs effects.

It is well recognized that estrogens and their receptors have a profound involvement in uterine pathology. Consistent with this concept, increased sensitivity to E2 may predispose to endometrial dysfunction and/or disease development. Some EDCs have been demonstrated to increase E2 responses in hormone-sensitive tissues and promote the development of tissue lesions and carcinogenesis later in life. Perinatal exposure of female rodents to low doses of BPA has been shown to enhance sensitivity of the mammary gland to E2 at puberty (Muñoz-de-Toro et al. 2005, Wadia et al. 2007) and to elicit the development of mammary carcinomas during adulthood in the absence of any additional treatment (Acevedo et al. 2013). Other authors have also reported that developmental exposure to BPA alters uterine and prostate gland response to E2 in aged rats, causing increased incidence of pre-neoplastic lesions in the uterus (Vigezzi et al. 2015, 2016) and intraepithelial neoplasia in the prostate (Ho et al. 2006). Similarly, mice postnatally exposed to low doses of DES with an enhanced uterine response to $\mathrm{E} 2$ at puberty (Newbold et al. 2004) developed uterine endometrial adenocarcinoma later in life (Newbold et al. 1990). In the present study, we found that early postnatal exposure to GBH altered uterine response to $\mathrm{E} 2$ in prepubertal rats. These results may indicate that postnatal GBH exposure could predispose to endometrial pathologies such as carcinogenesis in aged rats.

In conclusion, our results showed that postnatal exposure to GBH enhances the sensitivity of the rat uterus to estradiol and induces histomorphologic and molecular changes associated with uterine hyperplasia. GBH treatment induced morphological, cellular and molecular alterations in the rat uterus that were evidenced by the development of uterine hyperplasia, increase in E2-induced cell proliferation, induction of both ESR1 and ESR2 and deregulation of WNT/CTNNB1 signaling pathway. Currently, further experiments are underway to investigate whether subsequent estrogen exposure associated with puberty could induce benign and/or malignant tumors of female reproductive tissues in postnatally GBH-exposed rats.

\section{Declaration of interest}

The authors declare that there is no conflict of interest that could be perceived as prejudicing the impartiality of the research reported. 


\section{Funding}

This work was supported by grants from Consejo Nacional de Investigaciones Científicas y Técnicas (PIP 2015 N¹1220150100338CO), and Agencia Nacional de Promoción Científica y Tecnológica (ANPCyT (PICT 2014) N¹522), Argentina. These funding sources were not involved in the study design, sample collection, analysis or interpretation of the data, the writing of the report, or the decision to submit the article for publication. M G S is a fellow of the CONICET. M M M, E H L and J V are Career Investigators of the CONICET.

\section{Acknowledgments}

The authors sincerely thank Juan Grant and Juan C Villarreal (UNL) for their technical assistance and animal care. They are most grateful to M D. Adriana Albertengo for technical assistance in histological analysis.

\section{References}

Acevedo N, Davis B, Schaeberle CM, Sonnenschein C \& Soto AM 2013 Perinatally administered bisphenol A as a potential mammary gland carcinogen in rats. Environmental Health Perspectives 121 1040-1046. (https://doi.org/10.1289/ehp.1306734)

Arregui MC, Lenardon A, Sanchez D, Maitre MI, Scotta R \& Enrique S 2004 Monitoring glyphosate residues in transgenic glyphosateresistant soybean. Pest Management Science 60 163-166. (https://doi. org/10.1002/ps.775)

Bai SH \& Ogbourne SM 2016 Glyphosate: environmental contamination, toxicity and potential risks to human health via food contamination. Environmental Science and Pollution Research International 23 18988-19001. (https://doi.org/10.1007/s11356-016-7425-3)

Benbrook CM 2016 Trends in glyphosate herbicide use in the United States and globally. Environmental Sciences Europe 28 3. (https://doi. org/10.1186/s12302-016-0070-0)

Bonansea RI, Filippi I, Wunderlin DA, Marino DJG \& Ame MV 2017 The fate of glyphosate and AMPA in a freshwater endorheic basin: an ecotoxicological risk assessment. Toxics 6 1-13. (https://doi. org/10.3390/toxics6010003)

Bottner M \& Wuttke W 2005 Chronic treatment with low doses of estradiol affects pituitary and thyroid function in young and middleaged ovariectomized rats. Biogerontology 6 261-269. (https://doi. org/10.1007/s10522-005-2623-2)

Brembeck FH, Rosario M \& Birchmeier W 2006 Balancing cell adhesion and Wnt signaling, the key role of beta-catenin. Current Opinion in Genetics and Development 16 51-59. (https://doi.org/10.1016/j. gde.2005.12.007)

Bulun SE, Lin Z, Imir G, Amin S, Demura M, Yilmaz B, Martin R, Utsunomiya H, Thung S, Gurates B, et al. 2005 Regulation of aromatase expression in estrogen-responsive breast and uterine disease: from bench to treatment. Pharmacological Reviews $\mathbf{5 7}$ 359-383. (https://doi.org/10.1124/pr.57.3.6)

Bulun SE, Cheng YH, Pavone ME, Xue Q, Attar E, Trukhacheva E, Tokunaga H, Utsunomiya H, Yin P, Luo X, et al. 2010 Estrogen receptor-beta, estrogen receptor-alpha, and progesterone resistance in endometriosis. Seminars in Reproductive Medicine 28 36-43. (https:// doi.org/10.1055/s-0029-1242991)

Cassault-Meyer E, Gress S, Seralini GE \& Galeraud-Denis I 2014 An acute exposure to glyphosate-based herbicide alters aromatase levels in testis and sperm nuclear quality. Environmental Toxicology and Pharmacology 38 131-140. (https://doi.org/10.1016/j. etap.2014.05.007)

Chuffa LG, Lupi-Junior LA, Costa AB, Amorim JP \& Seiva FR 2017 The role of sex hormones and steroid receptors on female reproductive cancers. Steroids 118 93-108. (https://doi.org/10.1016/j steroids.2016.12.011)

Cikos S, Bukovská A \& Koppel J 2007 Relative quantification of mRNA: comparison of methods currently used for real-time PCR data analysis. BMC Molecular Biology 8 113. (https://doi.org/10.1186/14712199-8-113)

Cohn BA, La Merrill M, Krigbaum NY, Yeh G, Park JS, Zimmermann L \& Cirillo PM 2015 DDT exposure in itero and breast cancer. Journal of Clinical Endocrinology and Metabolism 100 2865-2872. (https://doi. org/10.1210/jc.2015-1841)

Defarge N, Takacs E, Lozano VL, Mesnage R, Spiroux de Vendomois J, Seralini GE \& Szekacs A 2016 Co-formulants in glyphosate-based herbicides disrupt aromatase activity in human cells below toxic levels. International Journal of Environmental Research and Public Health 13 1-17. (https://doi.org/10.3390/ijerph13030264)

Dixon D, Alison R, Bach U, Colman K, Foley GL, Harleman JH, Haworth R, Herbert R, Heuser A, Long G, et al. 2014 Nonproliferative and proliferative lesions of the rat and mouse female reproductive system. Journal of Toxicologic Pathology 27 1-107. (https://doi org/10.1293/tox.27.1S)

Durando M, Kass L, Piva J, Sonnenschein C, Soto AM, Luque EH \& Muñoz-de-Toro M 2007 Prenatal bisphenol A exposure induces preneoplastic lesions in the mammary gland in Wistar rats. Environmental Health Perspectives 115 80-86. (https://doi.org/10.1289/ ehp.9282)

EFSA 2015 Conclusion on the peer review of the pesticide risk assessment of the active substance glyphosate. EFSA Journal 13 4302. (https://doi. org/10.2903/j.efsa.2015.4302)

Florescu MM, Pirici D, Simionescu CE, Stepan AE, Margaritescu C, Tudorache S \& Ciurea RN 2016 E-cadherin and b-catenin immunoexpression in endometrioid endometrial carcinoma. Romanian Journal of Morphology and Embryology 57 1235-1240.

Gaetje R, Holtrich U, Karn T, Cikrit E, Engels K, Rody A \& Kaufmann M 2007 Characterization of WNT7A expression in human endometrium and endometriotic lesions. Fertility and Sterility 88 1534-1540. (https://doi.org/10.1016/j.fertnstert.2007.01.128)

Gasnier C, Dumont C, Benachour N, Clair E, Chagnon MC \& Seralini GE 2009 Glyphosate-based herbicides are toxic and endocrine disruptors in human cell lines. Toxicology 262 184-191. (https://doi. org/10.1016/j.tox.2009.06.006)

Guarino M, Rubino B \& Ballabio G 2007 The role of epithelialmesenchymal transition in cancer pathology. Pathology 39 305-318. (https://doi.org/10.1080/00313020701329914)

Guerrero Schimpf M, Milesi MM, Ingaramo PI, Luque EH \& Varayoud J 2017 Neonatal exposure to a glyphosate based herbicide alters the development of the rat uterus. Toxicology 376 2-14. (https://doi. org/10.1016/j.tox.2016.06.004)

Gundersen HJ, Bendtsen TF, Korbo L, Marcussen N, Moller A, Nielsen K, Nyengaard JR, Pakkenberg B, Sorensen FB \& Vesterby A 1988 Some new, simple and efficient stereological methods and their use in pathological research and diagnosis. Acta Pathologica, Microbiologica, et Immunologica Scandinavica 96 379-394. (https://doi. org/10.1111/j.1699-0463.1988.tb05320.x)

Gunin AG, Emelianov VU, Mironkin IU, Morozov MP \& Tolmachev AS 2004 Lithium treatment enhances estradiol-induced proliferation and hyperplasia formation in the uterus of mice. European Journal of Obstetrics, Gynecology and Reproductive Biology 114 83-91. (https://doi. org/10.1016/j.ejogrb.2003.09.023)

Hapangama DK, Kamal AM \& Bulmer JN 2015 Estrogen receptor beta: the guardian of the endometrium. Human Reproduction Update $\mathbf{2 1}$ 174-193. (https://doi.org/10.1093/humupd/dmu053)

Hendry WJ 3rd, Zheng X, Leavitt WW, Branham WS \& Sheehan DM 1997 Endometrial hyperplasia and apoptosis following neonatal diethylstilbestrol exposure and subsequent estrogen stimulation in both host and transplanted hamster uteri. Cancer Research $\mathbf{5 7}$ 1903-1908. https://joe.bioscientifica.com https://doi.org/10.1530/JOE-18-0207 (c) 2018 Society for Endocrinology Published by Bioscientifica Ltd. Printed in Great Britain 
Ho SM, Tang WY, Belmonte de Frausto J \& Prins GS 2006

Developmental exposure to estradiol and bisphenol A increases susceptibility to prostate carcinogenesis and epigenetically regulates phosphodiesterase type 4 variant 4. Cancer Research 66 5624-5632. (https://doi.org/10.1158/0008-5472.CAN-06-0516)

IARC Working Group on the Evaluation of Carcinogenic Risks to Humans 2015 Some organophosphate insecticides and herbicides. IARC Monographs 112 321-412.

Ingaramo PI, Varayoud J, Milesi MM, Guerrero Schimpf M, Muñozde-Toro M \& Luque EH 2016 Effects of neonatal exposure to a glyphosate-based herbicide on female rat reproduction. Reproduction 152 403-415. (https://doi.org/10.1530/REP-16-0171)

Ingaramo PI, Varayoud J, Milesi MM, Guerrero Schimpf M, Alarcon R, Muñoz-de-Toro M \& Luque EH 2017 Neonatal exposure to a glyphosate-based herbicide alters uterine decidualization in rats. Reproductive Toxicology 73 87-95. (https://doi.org/10.1016/j. reprotox.2017.07.022)

Kass L, Altamirano GA, Bosquiazzo VL, Luque EH \& Muñoz-de-Toro M 2012 Perinatal exposure to xenoestrogens impairs mammary gland differentiation and modifies milk composition in Wistar rats. Reproductive Toxicology 33 390-400. (https://doi.org/10.1016/j. reprotox.2012.02.002)

Leavitt WW, Evans RW \& Hendry WJ 3rd 1981 Etiology of DES-induced uterine tumors in the Syrian hamster. Advances in Experimental Medicine and Biology 138 63-86. (https://doi.org/10.1007/978-1-46157192-6_4)

Lerro CC, Koutros S, Andreotti G, Friesen MC, Alavanja MC, Blair A, Hoppin JA, Sandler DP, Lubin JH, Ma X, et al. 2015 Organophosphate insecticide use and cancer incidence among spouses of pesticide applicators in the Agricultural Health Study. Occupational and Environmental Medicine 72 736-744. (https://doi.org/10.1136/oemed2014-102798)

Liu Y, Meng F, Xu Y, Yang S, Xiao M, Chen X \& Lou G 2013 Overexpression of Wnt7a is associated with tumor progression and unfavorable prognosis in endometrial cancer. International Journal of Gynecological Cancer 23 304-311. (https://doi.org/10.1097/ IGC.0b013e31827c7708)

Mesnage R \& Antoniou MN 2018 Ignoring adjuvant toxicity falsifies the safety profile of commercial pesticides. Frontiers in Public Health 5 1-8. (https://doi.org/10.3389/fpubh.2017.00361)

Mesnage R, Phedonos A, Biserni M, Arno M, Balu S, Corton JC, Ugarte R \& Antoniou MN 2017 Evaluation of estrogen receptor alpha activation by glyphosate-based herbicide constituents. Food and Chemical Toxicology 108 30-42. (https://doi.org/10.1016/j. fct.2017.07.025)

Milesi MM, Varayoud J, Bosquiazzo VL, Muñoz-de-Toro M \& Luque EH 2012 Neonatal exposure to low doses of endosulfan disrupts the expression of proteins regulating uterine development and differentiation. Reproductive Toxicology 33 85-93. (https://doi. org/10.1016/j.reprotox.2011.12.003)

Milesi MM, Alarcon R, Ramos JG, Muñoz-de-Toro M, Luque EH \& Varayoud J 2015 Neonatal exposure to low doses of endosulfan induces implantation failure and disrupts uterine functional differentiation at the pre-implantation period in rats. Molecular and Cellular Endocrinology 401 248-259. (https://doi.org/10.1016/j.mce.2014.11.028)

Monje L, Varayoud J, Muñoz-de-Toro M, Luque EH \& Ramos JG 2009 Neonatal exposure to bisphenol A alters estrogen-dependent mechanisms governing sexual behavior in the adult female rat. Reproductive Toxicology 28 435-442. (https://doi.org/10.1016/j. reprotox.2009.06.012)

Muñoz-de-Toro MM, Maffini MV, Kass L \& Luque EH 1998 Proliferative activity and steroid hormone receptor status in male breast carcinoma. Journal of Steroid Biochemistry and Molecular Biology 67 333-339. (https://doi.org/10.1016/S0960-0760(98)00124-1)

Muñoz-de-Toro M, Markey CM, Wadia PR, Luque EH, Rubin BS, Sonnenschein C \& Soto AM 2005 Perinatal exposure to bisphenol-A alters peripubertal mammary gland development in mice. Endocrinology 146 4138-4147. (https://doi.org/10.1210/en.2005-0340)

Mutter GL, Zaino RJ, Baak JP, Bentley RC \& Robboy SJ 2007 Benign endometrial hyperplasia sequence and endometrial intraepithelial neoplasia. International Journal of Gynecological Pathology 26 103-114 (https://doi.org/10.1097/PGP.0b013e31802e4696)

Nakajima T, Tanimoto Y, Tanaka M, Chambon P, Watanabe H, Iguchi T \& Sato T 2015 Neonatal estrogen receptor beta is important in the permanent inhibition of epithelial cell proliferation in the mouse uterus. Endocrinology 156 3317-3328. (https://doi.org/10.1210/ en.2015-1012)

Newbold RR, Bullock BC \& McLachlan JA 1990 Uterine adenocarcinoma in mice following developmental treatment with estrogens: a model for hormonal carcinogenesis. Cancer Research 50 7677-7681.

Newbold RR, Jefferson WN, Padilla-Burgos E \& Bullock BC 1997 Uterine carcinoma in mice treated neonatally with tamoxifen. Carcinogenesis 18 2293-2298. (https://doi.org/10.1093/carcin/18.12.2293)

Newbold RR, Jefferson WN, Padilla-Banks E \& Haseman J 2004 Developmental exposure to diethylstilbestrol (DES) alters uterine response to estrogens in prepubescent mice: low versus high dose effects. Reproductive Toxicology 18 399-406. (https://doi.org/10.1016/j. reprotox.2004.01.007)

Newbold RR, Jefferson WN \& Padilla-Banks E 2007 Long-term adverse effects of neonatal exposure to bisphenol A on the murine female reproductive tract. Reproductive Toxicology 24 253-258. (https://doi. org/10.1016/j.reprotox.2007.07.006)

Niemann L, Sieke C, Pfeil R \& Solecki R 2015 A critical review of glyphosate findings in human urine samples and comparison with the exposure of operators and consumers. Journal für Verbraucherschutz und Lebensmittelsicherheit 10 3-12. (https://doi.org/10.1007/s00003014-0927-3)

Perego MC, Schutz LF, Caloni F, Cortinovis C, Albonico M \& Spicer LJ 2017 Evidence for direct effects of glyphosate on ovarian function: glyphosate influences steroidogenesis and proliferation of bovine granulosa but not theca cells in vitro. Journal of Applied Toxicology $\mathbf{3 7}$ 692-698. (https://doi.org/10.1002/jat.3417)

Peruzzo PJ, Porta AA \& Ronco AE 2008 Levels of glyphosate in surface waters, sediments and soils associated with direct sowing soybean cultivation in north pampasic region of Argentina. Environment and Pollution 156 61-66. (https://doi.org/10.1016/j.envpol.2008.01.015)

Portier CJ, Armstrong BK, Baguley BC, Baur X, Belyaev I, Belle R, Belpoggi F, Biggeri A, Bosland MC, Bruzzi P, et al. 2016 Differences in the carcinogenic evaluation of glyphosate between the International Agency for Research on Cancer (IARC) and the European Food Safety Authority (EFSA). Journal of Epidemiology and Community Health $\mathbf{7 0}$ 741-745. (https://doi.org/10.1136/jech-2015-207005)

Preisler-Mashek MT, Solodin N, Stark BL, Tyriver MK \& Alarid ET 2002 Ligand-specific regulation of proteasome-mediated proteolysis of estrogen receptor-alpha. American Journal of Physiology: Endocrinology and Metabolism 282 891-898. (https://doi.org/10.1152/ ajpendo.00353.2001)

Primost JE, Marino DJG, Aparicio VC, Costa JL \& Carriquiriborde P 2017 Glyphosate and AMPA, 'pseudo-persistent' pollutants under realworld agricultural management practices in the Mesopotamic Pampas agroecosystem, Argentina. Environment and Pollution 229 771-779. (https://doi.org/10.1016/j.envpol.2017.06.006)

Ramos JG, Varayoud J, Sonnenschein C, Soto AM, Muñoz-De-Toro M \& Luque EH 2001 Prenatal exposure to low doses of bisphenol A alters the periductal stroma and glandular cell function in the rat ventral prostate. Biology of Reproduction 65 1271-1277. (https://doi org/10.1095/biolreprod65.4.1271)

Ramos JG, Varayoud J, Bosquiazzo VL, Luque EH \& Muñoz-deToro M 2002 Cellular turnover in the rat uterine cervix and its relationship to estrogen and progesterone receptor dynamics. Biology of Reproduction 67 735-742. (https://doi.org/10.1095/ biolreprod.101.002402)
(C) 2018 Society for Endocrinology Published by Bioscientifica Ltd. Printed in Great Britain 
Ramos JG, Varayoud J, Monje L, Moreno-Piovano G, Muñoz-de-Toro M \& Luque EH 2007 Diethylstilbestrol alters the population dynamic of neural precursor cells in the neonatal male rat dentate gyrus. Brain Research Bulletin 71 619-627. (https://doi.org/10.1016/j. brainresbull.2006.12.004)

Richard S, Moslemi S, Sipahutar H, Benachour N \& Seralini GE 2005 Differential effects of glyphosate and roundup on human placental cells and aromatase. Environmental Health Perspectives 113 716-720. (https://doi.org/10.1289/ehp.7728)

Rivera OE, Varayoud J, Rodriguez HA, Muñoz-de-Toro M \& Luque EH 2011 Neonatal exposure to bisphenol A or diethylstilbestrol alters the ovarian follicular dynamics in the lamb. Reproductive Toxicology $\mathbf{3 2}$ 304-312. (https://doi.org/10.1016/j.reprotox.2011.06.118)

Rivera OE, Varayoud J, Rodriguez HA, Santamaria CG, Bosquiazzo VL, Osti M, Belmonte NM, Muñoz-de-Toro M \& Luque EH 2015 Neonatal exposure to xenoestrogens impairs the ovarian response to gonadotropin treatment in lambs. Reproduction 149 645-655. (https:// doi.org/10.1530/REP-14-0567)

Rodrigues NR \& de Souza APF 2017 Occurrence of glyphosate and AMPA residues in soy-based infant formula sold in Brazil. Food Additives and Contaminants, Part A: Chemistry, Analysis, Control, Exposure and Risk Assessment 20 1-8. (https://doi.org/10.1080/19440049.2017.1419286)

Saegusa M, Hashimura M, Yoshida T \& Okayasu I 2001 Beta-catenin mutations and aberrant nuclear expression during endometrial tumorigenesis. British Journal of Cancer 84 209-217. (https://doi. org/10.1054/bjoc.2000.1581)

Sanderson PA, Critchley HO, Williams AR, Arends MJ \& Saunders PT 2017 New concepts for an old problem: the diagnosis of endometrial hyperplasia. Human Reproduction Update 23 232-254. (https://doi. org/10.1093/humupd/dmw042)

Smith MS, Freeman ME \& Neill JD 1975 The control of progesterone secretion during the estrous cycle and early pseudopregnancy in the rat: prolactin, gonadotropin and steroid levels associated with rescue of the corpus luteum of pseudopregnancy. Endocrinology 96 219-226. (https://doi.org/10.1210/endo-96-1-219)

Solomon KR 2016 Glyphosate in the general population and in applicators: a critical review of studies on exposures. Critical Reviews in Toxicology 46 21-27. (https://doi.org/10.1080/10408444.2016.1214678)

Tarazona JV, Court-Marques D, Tiramani M, Reich H, Pfeil R, Istace F \& Crivellente F 2017 Glyphosate toxicity and carcinogenicity: a review of the scientific basis of the European Union assessment and its differences with IARC. Archives of Toxicology 91 2723-2743. (https:// doi.org/10.1007/s00204-017-1962-5)

Test Biotech 2013 High levels of residues from spraying with glyphosate found in soybeans in Argentina. Accessed on 28 June 2018. Munich, Germany: Testbiotech e.V. (available at: http://www.testbiotech.org/ en/node/926)

Thongprakaisang S, Thiantanawat A, Rangkadilok N, Suriyo T \& Satayavivad J 2013 Glyphosate induces human breast cancer cells growth via estrogen receptors. Food and Chemical Toxicology 59 129-136. (https://doi.org/10.1016/j.fct.2013.05.057)

Tica AA, Tica OS, Georgescu CV, Pirici D, Bogdan M, Ciurea T, Mogoanta SS, Georgescu CC, Comanescu AC, Balseanu TA, et al. 2016 GPER and ER alpha expression in abnormal endometrial proliferations. Romanian Journal of Morphology and Embryology 57 413-418.

US EPA 2015 EDSP: weight of evidence analysis of potential interaction with the estrogen, androgen or thyroid pathways. Chemical: glyphosate. Accessed 26 January 2018. Washington DC, USA: Office of Pesticide Programs US EPA. (available at: https://www.epa.gov/endocrine-disruption/endocrinedisruptor-screening-program-tier-1-screening-determinations-and)

US EPA 2017 Glyphosate. Dietary exposure analysis in support of registration review. Accessed 28 June 2018. Washington DC, USA: EPA. (available at: https://www.regulations.gov/document?D=EPA-HQOPP-2009-0361-0071)
Van Bruggen AHC, He MM, Shin K, Mai V, Jeong KC, Finckh MR \& Morris JG Jr 2018 Environmental and health effects of the herbicide glyphosate. Science of the Total Environment 617 255-268. (https://doi. org/10.1016/j.scitotenv.2017.10.309)

Vandenberg LN, Blumberg B, Antoniou MN, Benbrook CM, Carroll L, Colborn T, Everett LG, Hansen M, Landrigan PJ, Lanphear BP, et al. 2017 Is it time to reassess current safety standards for glyphosate-based herbicides? Journal of Epidemiology and Community Health 71 613-618. (https://doi.org/10.1136/ jech-2016-208463)

Van der Horst PH, Wang Y, Van der Zee M, Burger CW \& Blok LJ 2012 Interaction between sex hormones and WNT/B-catenin signal transduction in endometrial physiology and disease. Molecular and Cellular Endocrinology 358 176-184. (https://doi.org/10.1016/j. mce.2011.06.010)

Varayoud J, Ramos JG, Bosquiazzo VL, Muñoz-de-Toro M \& Luque EH 2008 Developmental exposure to bisphenol A impairs the uterine response to ovarian steroids in the adult. Endocrinology 149 5848-5860. (https://doi.org/10.1210/en.2008-0651)

Varayoud J, Ramos JG, Muñoz-de-Toro M \& Luque EH 2014 Long-lasting effects of neonatal bisphenol A exposure on the implantation process. Vitamins and Hormones 94 253-275. (https://doi.org/10.1016/B978-012-800095-3.00010-9)

Varayoud J, Durando M, Ramos JG, Milesi MM, Ingaramo PI, Muñoz-deToro M \& Luque EH 2017 Effects of a glyphosate-based herbicide on the uterus of adult ovariectomized rats. Environmental Toxicology 32 1191-1201. (https://doi.org/10.1002/tox.22316)

Vigezzi L, Bosquiazzo VL, Kass L, Ramos JG, Muñoz-de-Toro M \& Luque EH 2015 Developmental exposure to bisphenol A alters the differentiation and functional response of the adult rat uterus to estrogen treatment. Reproductive Toxicology 52 83-92. (https://doi. org/10.1016/j.reprotox.2015.01.011)

Vigezzi L, Ramos JG, Kass L, Tschopp MV, Muñoz-de-Toro M, Luque EH \& Bosquiazzo VL 2016 A deregulated expression of estrogentarget genes is associated with an altered response to estradiol in aged rats perinatally exposed to bisphenol A. Molecular and Cellular Endocrinology 426 33-42. (https://doi.org/10.1016/j. mce.2016.02.010)

Wada-Hiraike O, Hiraike H, Okinaga H, Imamov O, Barros RP, Morani A, Omoto Y, Warner M \& Gustafsson JA 2006 Role of estrogen receptor beta in uterine stroma and epithelium: insights from estrogen receptor beta-/- mice. PNAS 103 18350-18355. (https://doi. org/10.1073/pnas.0608861103)

Wadia PR, Vandenberg LN, Schaeberle CM, Rubin BS, Sonnenschein C \& Soto AM 2007 Perinatal bisphenol A exposure increases estrogen sensitivity of the mammary gland in diverse mouse strains. Environmental Health Perspectives 115 592-598. (https://doi. org/10.1289/ehp.9640)

Wang Y, Van der Zee M, Fodde R \& Blok LJ 2010 Wnt/b-catenin and sex hormone signaling in endometrial homeostasis and cancer. Oncotarget 1 674-684. (https://doi.org/10.18632/oncotarget.101007)

Weibel ER 1969 Stereological principles for morphometry in electron microscopic cytology. International Review of Cytology 26 235-302. (https://doi.org/10.1016/S0074-7696(08)61637-X)

Winuthayanon W, Hewitt SC, Orvis GD, Behringer RR \& Korach KS 2010 Uterine epithelial estrogen receptor alpha is dispensable for proliferation but essential for complete biological and biochemical responses. PNAS 107 19272-19277. (https://doi.org/10.1073/ pnas.1013226107)

Winuthayanon W, Hewitt SC \& Korach KS 2014 Uterine epithelial cell estrogen receptor alpha-dependent and -independent genomic profiles that underlie estrogen responses in mice. Biology of Reproduction 91 1-10. (https://doi.org/10.1095/ biolreprod.114.120170)
(C) 2018 Society for Endocrinology Published by Bioscientifica Ltd. Printed in Great Britain 
Yamashita S 2006 Expression of estrogen-regulated genes during development in the mouse uterus exposed to diethylstilbestrol neonatally. Current Pharmaceutical Design 12 1505-1520. (https://doi. org/10.2174/138161206776389840)

Yoshizawa K, Brix AE, Sells DM, Jokinen MP, Wyde M, Orzech DP, Kissling GE, Walker NJ \& Nyska A 2009 Reproductive lesions in female Harlan Sprague-Dawley rats following two-year oral treatment with dioxin and dioxin-like compounds. Toxicologic Pathology 37 921-937. (https://doi. org/10.1177/0192623309351721)

Zoller O, Rhyn P, Rupp H, Zarn JA \& Geiser C 2017 Glyphosate residues in Swiss market foods: monitoring and risk evaluation. Food Additives and Contaminants Part B/Surveillance 11 83-91. (https://doi.org/10.108 0/19393210.2017.1419509)

Received in final form 3 August 2018

Accepted 14 August 2018

Accepted Preprint published online 18 August 2018
๑) 2018 Society for Endocrinology Published by Bioscientifica Ltd. 